\title{
COPING IN A GLOBAL MARKETPLACE: SURVIVAL STRATEGIES FOR A 75-YEAR-OLD SEC
}

\author{
James D. Cox
}

$\mathrm{N}_{w}$ OTWITHSTANDING cynicism to the contrary, data bear witness to the fact that government agencies come and go. ${ }^{1}$ There are multiple causes that give rise to their disappearance, but two such causes are especially noteworthy. First, when the initial reasons that supported an agency's creation no longer exist so that the regulatory needs that once prevailed are no longer present; and second, when a shift in understanding of the regulatory issues occurs such that a different governmental response is now believed more appropriate the one Congress had embraced from when initially creating the agency. Certainly, the relative rigidity of the agency's mandate and authority has much to do with its ability to survive changes in the social, economic, commercial, and scientific forces that shape its environment. One of the great illustrations of the vibrancy of the regulatory agency model, and particularly the notion of equipping such an agency with "quasi-legislative" authority through broad enabling statutes, is the Securities and Exchange Commission. But can an agency created and operating through most of its years in the internationally insulated environment of U.S. capital markets survive in a world without borders such as today's global marketplace?

\footnotetext{
* Brainerd Currie Professor of Law, Duke University School of Law. The author benefitted greatly from the comments received at workshops at the schools of law of Duke University, University of Iowa, University of California, Berkeley, and Vanderbilt University as well as the conference convened in connection with this symposium and the helpful suggestions of Professors Stephen Choi, Jesse Fried, Robert Hillman, and Randall Thomas. I am particularly in the debt of the helpful research of Messrs. Adam Arkel, Christopher Fazekas, and Jonas Anderson.

${ }^{1}$ See David E. Lewis, The Politics of Agency Termination: Confronting the Myth of Agency Immortality, 64 J. Pol. 89, 92-93 (2002) (noting 62\% of agencies created since 1946 were terminated by 1997); see also David E. Lewis, Presidents and the Politics of Agency Design: Political Insulation in the United States Government Bureaucracy, 1946-1997, at 154 (2003) (noting the strongest variable contributing to an agency's survival is the degree to which it is insulated from political control, such as through party balancing within its leadership).
} 
There are many fundamental changes confronting the SEC today that invite reflection on whether the independent regulatory agency structure continues to be the optimal model. Indeed, the changes that have visited the SEC since it was a youthful fifty are staggering. ${ }^{2}$ Consider that the SEC's creation was part of the New Deal agenda that ultimately disentangled and kept separate commercial banking, insurance, and investment banking. Federal regulation was not seen as preemptive of the existing state blue sky laws, a view that reflected that much of what was to be regulated was local and not national. Consistent with this focused view of the markets was the reality that the principal market of America was the New York Stock Exchange ("NYSE"), and when later securities trading markets arose they, like the NYSE, were nonprofit membership organizations. And, when the SEC was created-and for most of its life-it oversaw a paper-based society in which securities offerings and trading were local, not international. The world has changed dramatically from those simpler days. In 1999, the Gramm-Leach-Bliley Act broke down the legislative walls that had separated commercial banking, investment banking, and insurance since the Great Depression. ${ }^{3}$ As a consequence, financial entities of all sizes now find their activities subject to multiple regulators. The federal-state partnership has been compromised by Congress repeatedly whittling back the permissible scope of state blue sky administrators. ${ }^{4}$ In addition, today's markets are profit centers that

\footnotetext{
${ }^{2}$ See the now classic symposium Fifty Years of Federal Securities Regulation, Symposium on Contemporary Problems in Securities Regulation, 70 Va. L. Rev. 545 (1984).

Gramm-Leach-Bliley Financial Services Modernization Act, Pub. L. No. 106-102, 113 Stat. 1338 (1999).

${ }^{4}$ The most overt evidence of this is the National Securities Markets Improvement Act of 1996, Pub. L. No. 104-290, 110 Stat. 3416 (1996), which preempted state regulation of securities offerings for covered securities. Id. $\$ 102$. Somewhat more subtle interference with state authority to protect its residents in securities transactions is evidenced by Congress' enactment of the Securities Litigation Uniform Standards Act of 1998 ("SLUSA"), Pub. L. No. 105-353, 112 Stat. 3227 (1998), which empowers defendants in certain securities class actions filed in state courts to seek the suit's removal to federal court so that federal, not state, standards will be applied to determine their liability. Id. § 101. See, e.g., Merrill Lynch, Pierce, Fenner \& Smith v. Dabit, 547 U.S. 71 (2006) (invoking SLUSA to remove suit initiated in state court by class of nonselling investors to federal court where it was dismissed on the well-recognized purchaser-seller standing requirement, which would not have applied had the suit remained based solely on state law).
} 
are publicly traded, thus compromising the earlier vision that the markets themselves would share the regulatory task. ${ }^{5}$ Each of these reflects a significant shift in the platform supporting the original vision of the SEC, but by far the largest shift is the combination of the ubiquity of the Internet and the convention that trading and offerings are global so that markets are increasingly seamless. As a consequence, statesmanship among national regulators is not just valued but essential in today's regulation of U.S. capital markets.

The political debate today regarding the role of the SEC-or for that matter whether there is to be an SEC-is defined by the tsunami of globalization now engulfing the SEC. Certainly if we begin to look back on the SEC's initiatives over the past several years, we will see the most profound initiatives taken in response to globalization. Here we find the overarching strategy has been one of mutual recognition. To the cynic, this reflects the regulator's perspective that "if you cannot beat them, join them." A more supportive view of mutual recognition is that the strategy offers an efficient solution for coping with the reality that rival markets are converging toward American reporting and operational practices. ${ }^{6}$ That is, differences between U.S. and foreign regimes are slight so that true convergence between them is not necessary to assure investor protection. A dramatic embrace of mutual recognition occurred in late 2007 when the SEC lifted its seventy-five-year requirement that foreign issuers reconcile their financial reports to U.S. Generally Accepted Accounting Principles ("GAAP"). ${ }^{7}$ The SEC had earlier

\footnotetext{
${ }^{5}$ See Roberta S. Karmel, The Future of Corporate Governance Listing Requirements, 54 SMU L. Rev. 325, 347-52 (2001) (arguing that as exchanges demutualize they likely will find it unwise to maintain and enforce strong listing requirements so that federal regulation increasingly will extend to areas such as governance that heretofore has been their domain); Roberta S. Karmel, Turning Seats Into Shares: Causes and Implications of Demutualization of Stock and Futures Exchanges, 53 Hastings L.J. 367, 409-27 (2002); Norman S. Poser, The Stock Exchanges of the United States and Europe: Automation, Globalization, and Consolidation, 22 U. Pa. J. Int'l Econ. L. 497, 517, 532-39 (2001).

${ }^{6}$ See generally Ethiopis Tafara \& Robert J. Peterson, A Blueprint for Cross-Border Access to U.S. Investors: A New International Framework, 48 Harv. Int'l L.J. 31, 5359 (2007) (reviewing numerous considerations that support mutual recognition among countries with high, albeit differing, regulatory standards).

${ }^{7}$ See Acceptance from Foreign Private Issuers of Financial Statements Prepared in Accordance with International Financial Reporting Standards Without Reconciliation to U.S. GAAP, Securities Act Release No. 33-8879, 73 Fed. Reg. 986 (2008), reprinted in [2002 to Current Transfer Binder] Fed. Sec. L. Rep. (CCH) II 88,032 (Dec. 21,
} 
announced it might permit domestic firms to prepare their financial statements in accordance with International Financial Reporting Standards ("IFRS") rather than GAAP. ${ }^{8}$ And, in fall 2008 the SEC placed the death of GAAP, at least for securities disclosures, on the agenda by proposing that ultimately all U.S. issuers must comply with IFRS. ' Increasingly, the SEC's regulatory posture on financial reporting issues is one of accommodation to foreign issuers rather than its historical position of demanding obeisance to the U.S. way. ${ }^{10}$ These developments and others bear testament that technology has made the world a smaller and more integrated place for investors and firms seeking capital through public offerings. U.S.-based investors and issuers invest and raise capital in foreign markets at an ever-increasing pace; foreign investors acquire securities in U.S. capital markets and foreign issuers raise significant amounts of capital through public offerings in the United States. Indeed, there is an accelerating pace of such transnational investing and offerings. ${ }^{11}$

2007). Not only did the SEC eliminate the reconciliation requirement for foreign private issuers whose financial statements are prepared according to International Financial Reporting Standards ("IFRS") as issued by the International Accounting Standards Board ("IASB"), but it also qualified this condition to permit issuers to depart from strict adherence to IFRS on their treatment of fair value and hedge fund accounting that had drawn the disapproval of E.U. authorities in response to heavy lobbying by public companies. Id.

${ }^{8}$ See Concept Release on Allowing U.S. Issuers to Prepare Financial Statements in Accordance with International Financial Reporting Standard, Securities Act Release Nos. 33-8831, 72 Fed. Reg. 45,600 (proposed Aug. 14, 2007), reprinted in [2002 to Current Transfer Binder] Fed. Sec. L. Rep. (CCH) II 87,944 (Aug. 7, 2007).

${ }^{9}$ See Roadmap for the Potential Use of Financial Statements Prepared in Accordance with International Financial Reporting Standards by U.S. Issuers, Securities Act Release No. 33-8982, 73 Fed. Reg. 70,816 (proposed Nov. 21, 2008), reprinted in [2002 to Current Transfer Binder] Fed. Sec. L. Rep. (CCH) II 88,409 (Nov. 14, 2008).

${ }^{10}$ See, e.g., Exemption of Certain Foreign Brokers or Dealers, Exchange Act Release No. 34-58047, 73 Fed. Reg. 39,182 (proposed July 8, 2008), reprinted in [2002 to Current Transfer Binder] Fed. Sec. L. Rep. (CCH) II 88,235 (June 27, 2008) (proposing a conditional exemption permitting foreign brokers to represent U.S.-based investors premised on the SEC being satisfied of relative comparability of regulation by the foreign regulator of the foreign broker or dealer).

${ }^{11}$ For a thoughtful review of trend lines in cross-border offerings and trading, see Howell E. Jackson \& Eric J. Pan, Regulatory Competition in International Securities Markets: Evidence from Europe - Part II, 3 Va. L. \& Bus. Rev. 207 (2008) (detailing waning interest in U.S. markets by European issuers that predated the passage of Sarbanes-Oxley Act of 2002 ("SOX") reflecting the growing maturity of European markets that has, in turn, increased the willingness of U.S. institutions to trade in the or- 
As technology has made national borders seamless, it challenges the territorial orientation of securities regulations. In the past, nations governed the disclosure requirements that applied to securities transactions undertaken within their borders. For example, a Japanese firm seeking to list its securities on the NYSE had to comply with U.S. disclosure requirements, and if a U.S. investor purchased the Japanese issuer's security on the Tokyo Stock Exchange, that investor depended not on the protective provisions of the U.S. securities laws but on those laws that applied to Japanese companies. $^{12}$ This reality has not changed, except now the SEC provides that the Japanese issuer may use IFRS to satisfy its U.S. disclosure requirements. This Article will examine the social consequences of mutual recognition and what it portends for securities regulators around the globe..$^{13}$ Indeed, this Article's focus will be

dinaries in a foreign market rather than American Depositary Receipts in a U.S. market).

${ }^{12}$ The notable exception to such territoriality is the passport enjoyed by issuers within the European Union whereby compliance with the disclosure requirements of one member state permits an issuer to raise capital and to list its securities in another member state without the necessity of satisfying the disclosure requirements of that state. This approach, however, requires that each member state's laws satisfy the minimum requirements broadly called for by the various directives of the European Union. See Parliament and Council Directive, Directive 2003/71/EC, 2003 O.J. (L345) 64 (imposing standard of maximum harmonization of listing particulars across member states as well as requiring members to permit offerings within their borders of security offerings approved by another member state's regulatory authority).

${ }^{13}$ There are at least three distinct regulatory paths that diverge from the status quo. One path leads us to multilateral agreements whereby participating nations agree to a single set of disclosure standards, which would be applied to companies of all signatory nations. Another path takes us in a different regulatory direction where, instead of a single, monolithic set of mandatory disclosure requirements, globalization may instead lead to multiple standards to be represented in a single market. Such an approach essentially collapses into their home market the environment in which all investors have access to a world market where there are numerous disclosure regimes. The third approach is a mixture of the two preceding alternatives.

The focus of multilateral agreements would be to establish minimum disclosure standards among signatory nations, but allow some nations to impose more demanding requirements. The template for this third approach is the set of practices authorized within the European Community ("E.C."). The cornerstones of securities regulation in the European Community are the principles of minimum standards and mutual recognition, whereby minimum disclosure standards for members are set by various E.C. directives and an issuer's compliance with the requirements of one member provides it with a "passport" to sell or list its securities within another member state. Interestingly, a few member countries impose disclosure requirements substantially more rigorous than the minimum level demanded by the applicable E.C. di- 
even broader in revealing that globalization forces us to rethink the ultimate role of securities regulation in an environment of global trading and offerings.

\section{THE GAAP-IFRS DIVIDE}

Despite having a nearly decade-long unwavering commitment to convergence in accounting principles during which there have been significant cooperative efforts on both sides of the Atlantic, GAAP and IFRS today are hardly mirror images of one another. ${ }^{14}$ The most dramatic evidence of their dissimilarities is not gleaned by close analysis of their arcane provisions but simply by hefting each set of accounting standards. When the various statements that comprise GAAP are "stacked" side by side with IFRS pronouncements, the latter is dwarfed by nearly a foot. This reflects not the

rectives. Thus, within the European Community, multiple standards can exist within a single market. An approach significantly more extreme than that within the European Community would occur if there were no agreement respecting minimum standards. A significantly more extreme approach than that of the European Community would involve no agreement respecting minimum standards ... This is the regulatory path suggested by the second alternative. To the extent that all of the above approaches lead to some form and scope of mandatory disclosure requirements, they each provide at least one obvious advantage to investors: the avoidance of added transaction costs investors now incur if they place their trades in a country different from the one in which they live. This reduces the costs they now incur when they make an investment choice that also substitutes the protections of their home country's securities laws for those of the country hosting their purchase or sale. One may well see that such a future approach, in which the applicable disclosure laws are not determined solely by the host country, is an ever-increasing reality as the natural movement toward a globalized economy occurs. Stephen J. Choi \& Andrew T. Guzman, Portable Reciprocity: Rethinking the International Reach of Securities Regulations, $71 \mathrm{~S}$. Cal. L. Rev. 903 (1998) (reasoning that in the face of globalization of capital markets issuers should enjoy broad choice of the laws guiding their disclosure requirements).

${ }^{14}$ See William W. Bratton \& Lawrence A. Cunningham, Treatment Differences and Political Realities in the GAAP-IFRS Debate, Appendix, 95 Va. L. Rev. 1009-23 (2009) (providing a careful and detailed comparison of major reporting items isolating important differences that persist between the two sets of standards). The distance that separates IFRS from GAAP has created opposition to the abolition of the GAAP reconciliation. See, e.g., Letter from Jack Ciesielski, Member, FASB Investors Technical Advisory Comm., to Nancy M. Morris, Secretary, SEC (Aug. 31, 2007) ("To eliminate the reconciliation at this time would amount to nothing more than achieving convergence by decree, rather than by achieving it in fact."), available at http://sec.gov/comments/s7-13-07/s71307-16.pdf; Steve Burkholder, FASB Panel Opposes SEC Proposal to Drop Reconciliation for IFRS Filers, 39 BNA Sec. Reg. L. Rep. 1414-15 (2007). 
incompleteness of coverage by IFRS but rather its lack of detail, what most attribute to IFRS being principles-based as contrasted with the more detailed, rules-based orientation of GAAP. The generality of IFRS reflects mainly where it has been, or better yet, where it has not been. IFRS, unlike GAAP, is developed as a body of reporting standards applicable to multiple cultures. Its wide adoption is reflective of its malleable quality that allows it to be applied across differing industries and business cultures. Moreover, it lacks the decades-long accretion of experience that has shaped GAAP. Thus, while championed as the model for principles-based regulation, IFRS may more aptly be understood as a youthful, multi-cultured filter for financial reporting. The effects that flow from the significant differences in the orientation and girth between GAAP and IFRS have been much examined. ${ }^{15}$

The fertile areas for investigation of the differences between GAAP and IFRS are the reported assets, liabilities, and income statement items used by foreign issuers when satisfying the earlier requirement that they reconcile their financial statements to GAAP. Such reconciliations occur annually on SEC Form 20-F, which mandates that foreign issuers identify the material differences between GAAP and IFRS (or other reporting standards used in the foreign issuer's home country in preparing its reports) and disclose the numerical impact of that difference on income and owners' equity.

IFRS enjoys broad popularity around the world. The chairman of the International Accounting Standards Board ("IASB") reports that the number of countries embracing IFRS is about 100 (with many more expected), whereas only a minority adhere to GAAP. ${ }^{16}$ The principles-based orientation of IFRS and the flexibility it provides in reporting a firm's financial performance and position explain its greater popularity. ${ }^{17}$ The attractiveness of a uniform set of principles-based standards culminated in the European Un-

\footnotetext{
${ }^{15}$ See infra notes - .

${ }^{16}$ Geoffrey Pickard, Simplifying Global Accounting: IASB Chair Discusses the Future of IFRS, U.S. GAAP and the Global Accounting Profession, J. Acct., July 2007, at 36 .

${ }^{17}$ See, e.g., Lawrence A. Cunningham, The SEC's Global Accounting Vision: A Realistic Appraisal of a Quixotic Quest, 87 N.C. L. Rev. 1, 15-16 (2008) (noting IFRS "qualities of looseness and vagueness and the absence of detail and guidance became an asset" in the surge of adoptions around the globe in the early 2000s).
} 
ion mandating that all E.U.-listed firms must, beginning in 2005, report in accordance with IFRS, thus striking a fatal blow to provincial country-based European reporting standards. ${ }^{18}$ Foreign issuers whose shares were listed in the United States, and who therefore were required to provide the annual reconciliation to GAAP, reaped a benefit for their managers, since using IFRS yielded increases in reported income over what would have been reported pursuant to their former country-based accounting. ${ }^{19}$ The wonders of IFRS alchemy propelled it to a most-favored position around the globe, but it also creates a cause for concern, which appears in a study of 2005 and 2006 reconciliations to GAAP by seventy-three European IFRS reporting issuers. Eighty-two percent of the companies had materially higher net income under IFRS than under GAAP.$^{20}$ The study concludes, somewhat wistfully, "if [U.S.] companies were given the option to use IFRS rather than [U.S.] GAAP then this would provide a boost to book earnings and returns." ${ }^{21}$

Among the problems encountered by researchers examining the earlier mandated Form 20-F reconciliations is that the examined foreign issuers may not have been reporting according to IFRS, as issued by the IASB, but rather according to a home country variation of IFRS. That is, the differences reported above may well be magnified by country-specific deviations from the IFRS's standards embraced by the IASB. ${ }^{22}$ Indeed, accountants do not disclose whether the IFRS standards being employed are those promulgated by the IASB or are a home country variation of IFRS. The

\footnotetext{
${ }^{18}$ Eur. Parl. Doc. (PE 308.463) (2002), available at http://www.europarl.europa.eu/ meetdocs/committees/juri/20020225/461067EN.pdf.

${ }^{19}$ Donna L. Street, Council of Institutional Investors, International Convergence of Accounting Standards: What Investors Need to Know 11-13 (2007).

${ }^{20}$ David Jetuah, Citigroup Lays Out IFRS-US GAAP Gulf, Acct. Age, Aug. 30, 2007, at 9 (noting mean net income was $23 \%$ greater and median net income reported under IFRS was $6 \%$ greater than GAAP).

${ }^{21}$ Id.

${ }^{22}$ For example, the U.K. Financial Services Authority recently observed that inconsistent national applications of IFRS across European countries was a major problem with IFRS reporting. Fin. Servs. Auth., Financial Risk Outlook 2007, at 112 (2007) ("[U]nder a principles-based accounting framework, there may be relevant economic and legal differences between countries such that similar transactions might legitimately be reported in different ways.... [S]hould local custom or national interest operate to threaten the consistent application of IFRS, much of this anticipated benefit could be lost.").
} 
IFRS's principles-based approach allows for certain judgments in this area, but the potential for manipulation at minimum calls for greater transparency so users can determine whether a firm has made its reporting decisions within the acceptable outer limits of the principles-based IFRS, as set out by the IASB. ${ }^{23}$

History suggests there may well be a lurking compliance problem with the SEC's current position. The rage in the late 1990s was the German Neuer Markt whose issuers were required to conform their financial reports to then-existing International Accounting Standards ("IAS") or GAAP. After the collapse of that market because of the failures of so many of its listed companies, it appears that there was significant non-compliance with this reporting requirement by listed companies. ${ }^{24}$ This suggests that the quality of reporting is not solely a matter of the metrics by which reporting items are to be measured but, more significantly, that company compliance with the stated metric is linked to how effective enforcement efforts are in the issuer's home market to assure compliance. That is, the quality of reporting is likely dependent more on the enforcement oversight in the issuer's home country than it is on the quality of the reporting metric itself.

A further concern is that the IASB and the reporting standards it adopts will continue to reflect the discrete intrusions of those who are to be governed by the standards. The IASB's current financial structure invites public and private incursions on its independence since its funding depends not only on voluntary contributions, but also voluntary contributions from the private, issuerdominated sector, which in actuality comprise its largest source of funding. ${ }^{25}$ It was because the FASB was dependent on voluntary contributions from the private sector that a central component of the Sarbanes-Oxley Act of 2002 ("SOX"), enacted in the wake of a

\footnotetext{
${ }^{23}$ This is a point made in a study counseling that it was premature to cast aside the reconciliation requirement because it was only through reconciliation that users can discern the extent of the deviation, if any, from the IASB promulgated version of IFRS. See Neri Bukspan \& Ron Joas, Standard \& Poor's, Commentary Report: The Road to Convergence: U.S. GAAP at the Crossroads 4 (2007).

${ }^{24}$ Martin Glaum \& Donna L. Street, Compliance with the Disclosure Requirements of Germany's New Market: IAS Versus US GAAP, 14 J. Int'l Fin. Mgmt. \& Acct. 64, 64 (2003).

${ }^{25}$ See Press Release, IASB, Update on Funding for 2008 (Feb. 4, 2008), available at http://www.iasb.org/News/Press+Releases/Update+on+Funding+for+2008.htm.
} 
national revulsion to the extensive financial frauds by public companies that came to light in 2001, mandates independence in funding as a precondition for SEC recognition of a body as an authoritative accounting standard setter. ${ }^{26}$ After the passage of SOX, the FASB is funded by fees assessed against reporting companies. The IASB is not funded in this manner and thus its independence from political pressures remains an important concern. ${ }^{27}$ For example, less than one year after the IASB was formed from the reorganization of its predecessor, which was believed to have lacked sufficient independence, ${ }^{28}$ the newly installed IASB chairman complained that powerful donors had threatened to withdraw their financial support if the IASB did not show greater consideration of their views in future deliberations. ${ }^{29}$ Most recently, the IASB, under pressure from E.U. members and the banking community, embraced a change in accounting classification of financial derivatives that will allow banks to avoid recognizing billions of dollars in losses attributable to the substantial decline in values related to the credit crisis. ${ }^{30}$ While such pressures have been evident in the United States, they have not caused the FASB to buckle in the same manner as the IASB.

We therefore can see that very different environments surround the development and utilization of IFRS and GAAP. Importantly,

\footnotetext{
${ }^{26}$ Sarbanes-Oxley Act of $2002 \S 108$ (b)(1)(A)(iii) (amending Securities Act Section 19(b), 15 U.S.C. 77s (requiring funding as set forth in Section 109)) (funding shall come from "accounting support fees" that are imposed upon reporting companies in proportion to each firm's share of the average equity market capitalization of all firms).

${ }^{27}$ See, e.g., Walter Mattli \& Tim Büthe, Global Private Governance: Lessons From a National Model of Setting Standards in Accounting, 68 Law \& Contemp. Probs., Summer 2005, at 225, 254 (collecting data that reflects both IASB and pre-SOX FASB heavy dependence on Big Five (now the Big Four) accounting firms and their audit clients for funding).

${ }^{28}$ See David S. Ruder et al., Creation of World Wide Accounting Standards: Convergence and Independence, 25 Nw. J. Int'l L. \& Bus. 513, 526-27, 536-37 (2005) (reviewing the evolution of the IASB toward greater independence from industry influence).

${ }^{29}$ Mattli \& Büthe, supra note 27, at 254.

${ }^{30}$ See Sara Schaefer Muñoz, EU Banks Get Leeway on Making Write-Downs, Wall St. J. Oct. 20, 2008, at C1 (discussing how the change allows banks to reclassify investments as long-term and beyond the "mark-to-market" requirement and given the lax enforcement that prevails in the European Union, analysts fear that such reclassification will not be rare but rampant).
} 
the resulting reporting metrics of each body of standards reflect these cultural differences. Accordingly, IFRS and GAAP are not mirror images of one another and there is little cause to believe that they will ever be. To be sure, there may well be relatively brief moments of time of true convergence, but since the cultural forces that shape each are not themselves correlated with one another, we cannot expect these standards to be identical. More important, because IFRS is intended to reach across continental borders such that it is truly a set of multi-cultural accounting standards, IFRS will always call for greater generality than we can expect for the more culturally focused standard, GAAP. Hence, IFRS of necessity is principles-based such that it naturally invites more discretion and choice than GAAP embraces for the discrete lore of financial reporting. Thus, in a capital market in which both IFRS and GAAP exist, managers of reporting issuers enjoy a choice of real significance, but allowing them such choice comes with costs to the ability of securities regulators to perform their functions.

\section{MANDATORY Disclosure AND THE MisSION OF THE SECURITIES LAwS}

Choice generally is a wonderful thing. With choice there is the freedom to pursue what one believes is in his best interest. Choice, therefore, is the cornerstone of our market-based economy since it is the consumer's freedom to choose that guides production and ultimately to what production functions capital is directed. More productive uses are funded and at a higher return on investment compared with ventures that are seen as less attractive. Importantly, in seeking capital, producers have a choice as well, not only with respect to how they will finance their projects, but also in today's global market where they will seek that financing.

Even though there is a worldwide commitment to the allocational function of capital markets, each country shapes the capital raising process by its own set of mandatory disclosure rules. Thus, although the securities laws of nations share common goals, they vary widely in how they seek to achieve these objectives. Investors, therefore, not only enjoy a choice of investment opportunities, but they also enjoy choice among competing markets, which are distin- 
guished by, among other features, their differing regulatory regimes. ${ }^{31}$ For example, baseline disclosure requirements for offerings and trading in securities in the United Kingdom are regulated by the Financial Services Administration, while those in the United States are regulated by its SEC, and so forth. Correlatively, the securities regulator's jurisdiction is confined to the borders of the nations in which it is located so that transactions within its jurisdiction are regulated exclusively by its disclosure rules, even though investors and issuers may prefer a different regime. ${ }^{32}$ In this way, each securities regulator enjoys a regulatory monopoly over securities transactions within its nation's borders.

To apprise how regulators should respond to the threat that globalization poses to their regulatory monopolies, we need to under-

\footnotetext{
${ }^{31}$ To be sure, investors and issuers who prefer opportunities governed by one regulatory regime over those of their home country can direct their transactions to that jurisdiction. Thus, choice does exist, but its exercise entails additional costs to both the issuer and the investor that would not exist if the issuer and the investors could have matched their interest in their home jurisdiction rather than in another regulatory jurisdiction. The benefits of this choice for issuers flows from the issuer's management opting for the higher standards and enforcement of the host market as a way of signaling management's confidence that they pose fewer risks to investors than their counterparts who do not choose to so bond themselves by obtaining a secondary listing in the higher regulation market. See John C. Coffee, Jr., Racing Towards the Top?: The Impact of Cross-Listings and Stock Market Competition on International Corporate Governance, 102 Colum. L. Rev. 1757, 1779-97 (2002) (arguing foreign firms overcome weak home country shareholder protections by cross-listing in the United States). For a review of the fundamental components of the securities laws across major markets, see Marc I. Steinberg \& Lee E. Michaels, Disclosure in Global Securities Offerings: Analysis of Jurisdictional Approaches, Commonality and Reciprocity, 20 Mich. J. Int'l L. 207, 210-35 (1999).

${ }^{32}$ In any country, there is always the option for issuers to provide greater disclosure than required by the host country where the issuer believes this is in its best interest. The regulatory rubber hits the pavement where the issuer and investors may prefer less disclosure than is mandated in the host country. It is the latter-less disclosuresituation in which the issue of menus exists. In the former situation-more disclosure - there is no serious conflict between regulators, issuers, and investors.

The territorial orientation of a nation's jurisdiction to prescribe and to enforce its regulatory objectives is the predominant approach, so that exceptions arise in those rare instances when conduct committed outside its borders threatens harm or causes actual harm to its national interest. See Restatement (Third) of Foreign Relations Law of the United States $\S \S 402-03$ (1986); id. $§ 402$ n.1. See generally James D. Cox et al., Securities Regulation: Cases and Materials 1131-42 (5th ed. 2006). The U.S. jurisdiction to prescribe in the securities area is even more narrowly based on territorial considerations. See Restatement (Third) of Foreign Relations Law of the United States $§ 416(1986)$.
} 
stand the overall pricing function of markets. There is a good deal of debate regarding not only whether securities markets are efficient, ${ }^{33}$ but more fundamentally what the meaning of market efficiency is. ${ }^{34}$ This Article proceeds first on the assumption that security prices are fundamentally efficient, which is to say that investors

${ }^{33}$ For a close review of the twists and turns of the debate surrounding the meaning and implications of the efficient market hypothesis, see Lawrence A. Cunningham, From Random Walks to Chaotic Crashes: The Linear Genealogy of the Efficient Capital Market Hypothesis, 62 Geo. Wash. L. Rev. 546 (1994). For a review of evidence at odds with the efficient market hypothesis, see Kent Daniel et al., Investor Psychology and Security Market Under- and Overreactions, 53 J. Fin. 1839 (1998). The weakest link in the efficient market hypothesis is the rational actor model of investor behavior and the presence of arbitrage by sophisticated investors to overcome any pricing imbalances that arise because of irrational or other actors' distortions. See generally Andrei Shleifer, Inefficient Markets: An Introduction to Behavioral Finance 10-16 (2000) (reviewing a number of theories from behavioral literature that weigh against efficient pricing of securities); Andrei Shleifer \& Robert W. Vishny, The Limits of Arbitrage, 52 J. Fin. 35 (1997) (detailing how arbitrage likely is ineffective in correcting prices during conditions of extreme volatility); Lynn A. Stout, The Mechanisms of Market Inefficiency: An Introduction to the New Finance, 28 J. Corp. L. 635 (2003) (providing an insightful review of literature challenging the conventional efficient market hypothesis and concluding the literature better supports a model of heterogeneity among investors where stock prices mechanisms are more aptly captured by behavioral finance models). On the one hand, carried to its logical conclusion, a behavioral finance-based model of stock pricing mechanisms can be seen as calling for greater SEC-driven paternalism. See Donald C. Langevoort, Taming the Animal Spirits of the Stock Markets: A Behavioral Approach to Securities Regulation, 97 Nw. U. L. Rev. 135, 185-88 (2002) (arguing behavioral insights should be incorporated into the cost-benefit assessments of regulatory initiatives); Robert Prentice, Whither Securities Regulation? Some Behavioral Observations Regarding Proposals for Its Future, 51 Duke. L.J. 1397, 1485-94, 1509-11 (2002) (justifying mandatory disclosure regulation as necessary to address a range of cognitive biases common to investors). On the other hand, such a model could justify a much more circumscribed approach to regulation. See generally Stephen J. Choi \& A.C. Pritchard, Behavioral Economics and the SEC, 56 Stan. L. Rev. 1 (2003) (arguing that cognitive biases also impact the SEC's administration of the securities laws so that in combination the value of regulation is drawn further into question). For more sweeping criticism, see Robert A. Haugen, The New Finance: The Case Against Efficient Markets (1995) (providing a critical quantitative review of theory and evidence frequently invoked to support the efficient market hypothesis).

${ }^{34}$ See, e.g., Robert C. Merton, A Simple Model of Capital Market Equilibrium with Incomplete Information, 42 J. Fin. 483 (1987) (reasoning that market efficiency is a useful abstraction in that the model offers the best description of securities pricing in the long run, albeit subject to limited precision). In the end, we might conclude that Professor Merton is correct: "[T]he perfect-market model of efficiency may be a useful abstraction ... [but we should] be cognizant of the insensitivity of this model to institutional complexities and explicitly assess the limits of precision that can be reasonably expected from its predictions.” Id. at 486. 
impound in their trading beliefs respecting the intrinsic value they attach to an additional unit of disclosure. ${ }^{35}$ Simply put, this Article's initial assumptions are that market forces accurately price the risks posed by a security and that to the extent two securities are similar in all respects except that one security provides an additional unit of disclosure that the investors believe relevant and the other security does not, investors not only distinguish between the two securities but also rationally price the consequences of the differing disclosures made between the two securities. With a market that is so efficient, our comfort level in a regulatory strategy that permits parties to opt for the reporting metrics of their choice-for example, GAAP or IFRS - should be influenced by our belief that the security will be accurately priced to reflect the bargain that is struck including the disclosure risk implicit in that bargain. ${ }^{36}$

Nobel Laureate George Akerlof's "market for lemons" provides the framework for illustrating the pricing of securities in a market that is fundamentally efficient when there are differing disclosure

\footnotetext{
${ }^{35}$ That markets operate so that new information not only becomes rapidly embedded in the security's price but also the resulting price reflects the security's intrinsic value is sometimes referred to as fundamental market efficiency. It has wisely been observed that there is a less efficient state, namely, that security prices may well rapidly reflect new information but the security's price will not necessarily align with its fundamental/intrinsic value. See Mark Rubinstein, Securities Market Efficiency in an Arrow-Debreu Economy, 65 Am. Econ. Rev. 812, 820-23 (1975) (contrasting informational efficiency with fundamental efficiency); Lawrence H. Summers, Does the Stock Market Rationally Reflect Fundamental Values?, 41 J. Fin. 591 (1986); James Tobin, On the Efficiency of the Financial System, Lloyds Bank Rev. 1 (July 1984).

${ }^{36}$ Because of the importance to investors that they be able to price regulatory disclosure differences across issuers, we can understand why it is equally important to policymaking whether disclosure gaps arising under one disclosure regime vis-à-vis a more demanding regime can be priced in the market. For an insightful analysis of how we might measure whether particular disclosure policies enhance share price accuracy, see Merritt B. Fox, Measuring Share Price Accuracy, 1 Berkeley Bus. L.J. 113 (2004) (arguing that the best proxy of share price accuracy for an individual security is the degree of correlation with movement of all other firms in the economy). See generally Merritt B. Fox et al., Law, Share Price Accuracy, and Economic Performance: The New Evidence, 102 Mich. L. Rev. 331 (2003) (presenting evidence that the SEC's mandated management discussion and analysis disclosures improve share-price accuracy and concluding such improvement contributes to allocational efficiency). For insight as to what might explain such correlation differences across developing and emerging markets, see Allen Ferrell, If We Understand the Mechanisms, Why Don't We Understand Their Output?, 28 J. Corp. L. 503 (2003).
} 
metrics for issuers in the same market. ${ }^{37}$ Assume that all securities are the same except that one-half have an intrinsic value per share of $\$ 22$ (the $X$ Issuers) and the value for the other half is $\$ 20$ (the $Y$ Issuers) ${ }^{38}$ Assume further that even under the existing disclosure requirements, investors will be unable to distinguish $X$ Issuers from $Y$ Issuers. Without additional disclosures, $X$ and $Y$ Issuer securities can be expected to trade at $\$ 21$ per share, so that the securities of $X$ Issuers are undervalued and those of $Y$ Issuers are overvalued. ${ }^{39}$ In the perfect world, $X$ Issuers find this result intolerable and Akerlof's insights predict that minimally $X$ will seek credible means to signal their true value or, failing that, the $X$ Issuer will at least not engage in offering their securities to investors for what the $X$ Issuer's managers know is a price that undervalues their worth. ${ }^{40}$

But the world is not perfect. Issuers are guided by their managers' utility functions, which may well cause them to conclude it is

\footnotetext{
${ }^{37}$ George A. Akerlof, The Market for "Lemons": Quality Uncertainty and the Market Mechanism, 84 Q.J. Econ. 488 (1970).

${ }^{38}$ While financial theory and empirical work focuses on security returns, for simplicity the illustrations in this Article deal with the ultimate effects of changes in return, namely the security's price.

${ }^{39}$ For a review of the literature on the impact disclosure has on the cost of equity capital, see Christine A. Botosan, Disclosure Level and the Cost of Equity Capital, 72 Acct. Rev. 323 (1997). One of the paradoxes of just such a view of capital markets is what incentives there are to reward arbitrageurs to drive securities to their intrinsic values. Does efficiency rest upon some mispricing in any case so as to provide significant rewards for arbitrage behavior? See Sanford J. Grossman \& Joseph E. Stiglitz, On the Impossibility of Informationally Efficient Markets, 70 Am. Econ. Rev. 393 (1980) (speculating that private information in the possession of arbitrageurs provides such rewards).

${ }^{40}$ See Frank H. Easterbrook \& Daniel R. Fischel, Mandatory Disclosure and the Protection of Investors, 70 Va. L. Rev. 669, 673-77 (1984). The resulting information hierarchy is consistent with studies that have found that increased levels of disclosure by firms reduce investor concerns respecting the informational advantages between the firm and outside investors such that when the firm offers its securities, the higher disclosing firms incur a lower cost of capital. See Douglas W. Diamond \& Robert E. Verrecchia, Disclosure, Liquidity, and the Cost of Capital, 46 J. Fin. 1325 (1991). The clear advantage of proceeding cautiously in designating what and when information must be disclosed is demonstrated by the possible harm that weakening rewards for incentive behavior can cause. That is, a clear cost of mandating a single disclosure standard is that the mandated requirement may be set too high in terms of the social costs it leads to, such as reducing the rewards for incentive behavior by greatly reducing any first mover advantage by alerting others to the gains the disclosing firm has garnered through its innovative efforts. See Edmund W. Kitch, The Theory and Practice of Securities Disclosure, 61 Brook. L. Rev. 763, 853-54 (1995).
} 
better for them to be lost in the crowd of $\$ 21$ issuers than to set themselves apart from that group. There are multiple reasons this strategy may be pursued by $X$ Issuers' managers. For example, to announce their true returns may attract competition and in the long run erode the secure existence managers seek. ${ }^{41}$ Managers may also contemplate taking the firm private at some future date (somewhat analogous to insider trading on a massive scale). Or, frankly, their stock options might not have been granted or those granted might not have vested, so that a future bump in the price is to their advantage. Finally, delaying recognition of a gain today may provide some reserve for moderating a future unexpected dip in the firm's value. ${ }^{42}$ The host market's securities regulator is disturbed not only by the fear that managers are not choir boys, but also by the fear that natural forces may well fail to induce action by managers to separate $X$ firms from $Y$ firms in the eyes of investors. Moreover, regulators genuinely fear that some groups of investors (those purchasing more $Y$ than $X$ securities) receive a below average return for the level of risk embraced. And, viewing the problem even more broadly, allocational concerns arise if either $X$ Issuers or $Y$ Issuers raise capital in transactions in which the market price for their respective security influences the issuer's cost of capital. Simply put, inaccurate securities prices impair the allocational efficiency of capital markets, a central objective of securities regulation.

\footnotetext{
${ }^{41}$ See Mary Stanford Harris, The Association Between Competition and Managers' Business Segment Reporting Decisions, 36 J. Acct. Res. 111, 111-12 (1998) (observing that in industries where there is low competition and abnormally high profits, managers are more unwilling to undertake segment reporting than their counterparts in competitive industries).

${ }^{42}$ See John R. Graham et al., The Economic Implications of Corporate Financial Reporting, 40 J. Acct. \& Econ. 3, 47 (2005) (finding more than three-fourths of 401 surveyed financial executives would give up economic value in exchange for smoother earnings).

A further concern is whether incentives to signal are stronger in large capitalization firms than smaller ones. The favorable impact on a firm's cost of capital arising from an incremental increase in disclosure flows from increased demand of large institutional investors who are-out of concerns for liquidity-more likely to populate larger market capitalized firms than smaller ones. This has caused some to reason that increased disclosure may produce more observable market responses for large market capitalization firms than for smaller firms. Diamond \& Verrecchia, supra note 40, at 1348-49.
} 
Thus, the securities regulator will consider disclosure requirements that will bring about greater pricing accuracy for securities. Suppose that the baseline disclosure requirements in the above illustration do not include line of business reporting requirements and that if such information were disclosed it would distinguish $X$ Issuers from $Y$ Issuers. ${ }^{43}$ The securities regulator could pursue the objective of improved pricing of securities and allocational efficiency by adopting line of business reporting so that investors are able to distinguish $X$ Issuers from $Y$ Issuers with the result that after this new information each security trades at its intrinsic value. Upon disclosure of line of business information, $X$ Issuers will trade at $\$ 22$ and the $Y$ Issuers will trade at $\$ 20 .^{44}$ As a result, the lemons market is avoided and allocational efficiency is enhanced.

\footnotetext{
${ }^{43}$ There is extensive literature demonstrating that disclosure of line of business information to investors has a significant effect on the price of the disclosing firm's securities. See, e.g., Philip G. Berger \& Rebecca Hann, The Impact of SFAS No. 131 on Information and Monitoring, 41 J. Acct. Res. 163, 164-67 (2003) (observing that heightened line of business reporting not only changed securities prices but also impacted firm behavior); Marilyn Magee Greenstein \& Heibatollah Sami, The Impact of the SEC's Segment Disclosure Requirement on Bid-Ask Spreads, 69 Acct. Rev. 179, 179-80 (1994) (showing statistically significant narrowing of spreads upon firms' initial disclosures of line of business information).

${ }^{44}$ This is consistent with the view that securities prices change in response to firm specific information due mostly to risk arbitrage. See Kenneth R. French \& Richard Roll, Stock Return Variances: The Arrival of Information and the Reaction of Traders, 17 J. Fin. Econ. 5, 5-6 (Sept. 1986); Richard Roll, R², 43 J. Fin. 541, 541-42 (1988). Fairly dramatic evidence of such a result was captured in a recent study of German companies that switched to the more rigorous reporting standards of GAAP or International Accounting Standards. Those switching considerably narrowed the bid-ask spread for their securities, a result consistent with investors' perceiving less risk with the information released by the switching firms. See Christian Leuz \& Robert E. Verrecchia, The Economic Consequences of Increased Disclosure, 38 J. Acct. Res. 91, 93 (Supp. 2000) (finding spreads were reduced and trading volume increased for German firms switching from their home country reporting standard to either IAS or GAAP); see also Brian J. Bushee \& Christian Leuz, Economic Consequences of SEC Disclosure Regulation: Evidence from the OTC Bulletin Board, 39 J. Acct. \& Econ. 233, 236 (2005) (noting that Over-The-Counter Bulletin Board traded firms that complied with the new requirement that they also become an SEC reporting company experienced a sharp increase in liquidity and returns versus those that failed to meet this requirement).

It should also be noted that changes in a securities return is not the only effect that one can expect with increased or reduced disclosure. Reduced levels of liquidity also are associated with lower disclosing firms. See, e.g., Thomas E. Copeland \& Dan Galai, Information Effects on the Bid-Ask Spread, 38 J. Fin. 1457 (1983); Lawrence R. Glosten \& Paul R. Milgrom, Bid, Ask and Transaction Prices in a Specialist Mar-
} 
The lemons problem comes into bold relief when we consider mutual recognition in the context of GAAP versus IFRS, particularly if this choice is available to domestic issuers as well as foreign issuers. As seen earlier, GAAP and IFRS are not mirror images of one another. Distinct differences exist in numerous areas bearing on the measurement of central financial reporting items. More importantly, the hallmark of IFRS is that the metrics for so many of its provisions are principles-based as contrasted with more specific rules-based proscriptions. This translates to greater indefiniteness in reporting results even among IFRS-compliant members since greater discretion is incorporated into the reporting standard, causing outcomes to vary across reporting companies. This introduces an interesting separation continuum among IFRS-compliant issuers.

To illustrate, consider variations on the preceding hypothetical where the host market has an equal number of GAAP compliant firms ( $G$ firms) and IFRS compliant firms ( $I$ firms). Within each of these two sets of firms, there are $G$ and $G^{\prime}$ firms and $I$ and $I$ ' firms with the difference being that the $G$ and $I$ firms' intrinsic value is $\$ 22$ and the $G$ ' and $I$ ' firms have intrinsic values of $\$ 20$. Because we further assume that compliance with GAAP effectively distinguishes the $G$ from the $G^{\prime}$ firms, each will be accurately priced at their intrinsic values, $\$ 22$ and $\$ 20$, respectively. However, because IFRS's principles-based orientation provides greater laxity around what appears in the ultimate reporting of each firm's financial performance and position, investors lack the information to distinguish the $I$ from the $I$ ' firms so that $I$ firm's will be underpriced and $I$ ' will be overpriced. To be sure, this may cause $I$ firms to migrate to GAAP, but for reasons set forth earlier, their firm's managers

ket with Heterogeneously Informed Traders, 14 J. Fin. Econ. 71 (1985). See generally Albert S. Kyle, Continuous Auctions and Insider Trading, 53 Econometrica 1315 (1985).

More generally, high disclosure quality yields lower costs of capital. See Partha Sengupta, Corporate Disclosure Quality and the Cost of Debt, 73 Acct. Rev. 459, 459-60 (1998) (noting that firms with a higher disclosure quality score were observed to have 110 basis points lower bond interest than firms having weakest disclosure score); Michael Welker, Disclosure Policy, Information Asymmetry, and Liquidity in Equity Markets, 11 Contemp. Acct. Res. 801, 803, 811 (1995) (displaying a study of 427 firms in twenty-eight industries, finding that spreads were $50 \%$ greater for firms ranked in the lowest third by disclosure score versus those ranked in the highest third). 
may avoid making the switch. It is into this world that the desirability of choice, in this case GAAP versus IFRS, should be assessed against the historical objectives of securities regulations.

There are four well-recognized interrelated objectives sought to be achieved by mandatory disclosure requirements of the securities laws. Each objective reflects the regulator's fear that his intervention is necessary to address a harmful market failure. First, mandatory disclosure is believed necessary to provide investors with information they need to make informed intelligent investment decisions. ${ }^{45}$ Stated simply, absent mandatory disclosure requirements, investors will not receive the information they need to assess competing investment opportunities; the information they do receive will vary widely across issuers so that comparability among them is not practicable. ${ }^{46}$ A core feature of this objective is comparability among investment choices, at least with respect to choices among securities competing for the investor's funds. Comparability implicates the scope and detail, and to a lesser extent its presentation format, of the information the regulator requires all issuers to disclose. Second, securities laws seek to enhance the allocational function of capital markets. ${ }^{47}$ Adam Smith's invisible hand is be-

\footnotetext{
${ }^{45}$ See, e.g., Int'l Org. of Sec. Comm'ns, Objectives and Principles of Securities Regulation 5-7 (2003), http://www.iosco.org/library/pubdocs/pdf/IOSCOPD154.pdf (listing among objectives protecting investors, fair, efficient, and transparent markets, and reducing systemic risk); Zohar Goshen \& Gideon Parchomovsky, The Essential Role of Securities Regulation, 55 Duke. L.J. 711, 737-39 (2006) (stating that the goal of securities laws is the efficient allocation of resources, which depends on disclosureenabling information traders to act in an informed manner).

${ }^{46}$ Note that investors may overcome some initial lack of comparability with the aid of information from other sources and additional effort (for example, to overcome differences in methodology used by issuers) to make meaningful comparisons. See, e.g., Shyam Sunder, Stock Price and Risk Related to Accounting Changes in Inventory Valuation, 50 Acct. Rev. 305, 312-14 (1975) (switching to higher cost LIFO from FIFO is not associated with any significant observable changes in firm's stock price). For this type of disclosure issue, the utility of mandating uniformity is to put upon the issuer the cost of uniformity in the belief this will result in lower overall costs vis-à-vis the collective costs of numerous investors undertaking individual efforts to acquire the same information.

${ }^{47}$ See Merritt B. Fox, Company Registration and the Private Placement Exemption, 51 Case W. Res. L. Rev. 455, 458-60 (2001) (asserting that the primary goal of securities regulation is efficiency in pricing cost of capital as it relates to the individual firm's selection of new investment projects); Goshen \& Parchomovsky, supra note 45, at 713 (asserting that the essential function of securities law is to attain efficient resource allocation). The connection between mandatory disclosure rules and the allo-
} 
lieved to operate more effectively if, on the basis of disclosed information, investors can differentiate risk and return relationships among competing opportunities. Mandatory disclosure rules are believed to facilitate allocational efficiency because uniform disclosure will lead to sharper comparative judgments respecting the relation of risk and return. Third, mandatory disclosure rules are justified as a useful prophylactic to reduce the frequency and scale of fraudulent offerings and other manipulative practices. The connection between mandatory disclosure rules and manipulative practices is illustrated by the pump-and-dump schemes that plague penny stock markets. ${ }^{48}$ A key feature of these schemes is public trading in securities of issuers about which there is no reliable public information. This permits the unscrupulous promoter to pique investor interest through rumors and false reports; with large numbers of credulous investors providing upward price momentum for the security, the promoter can dispose of her holdings at a substantial profit. Thus, mandatory disclosure rules fill what otherwise

cational function is easiest to understand with respect to issuer transactions as contrasted with trading transactions since issuer transactions are directly linked to the issuer's cost of capital with respect to its present offering. See, e.g., Jack Hirshleifer, The Private and Social Value of Information and the Reward to Incentive Activity, 61 Am. Econ. Rev. 561, 569-70 (1971). Financial theorists also support the link between risk-return judgments embodied in trading transactions and the allocation of capital among competing investment opportunities. James Tobin, On the Efficiency of the Financial System, Lloyds Bank Rev. 1, 5-8 (July 1984) (questioning whether informationally efficient markets necessarily also reflect fundamental value of the traded securities, but noting more meaningful stock prices plausibly improve allocation of capital); Artyom Durnev et al., Does Firm-Specific Information in Stock Prices Guide Capital Allocation?, 3-4 (Nat'l Bureau of Econ. Research, Working Paper 8093, Jan. 2001), available at http://www.nber.org/papers/w8093 (stating that firms with more firm-specific variation in their stock prices are hypothesized to trade in more efficient markets and study findings reflect such firms allocate capital with greater precision than firms whose securities are not classed as being priced in an efficient market. These connections are accepted by many as a fundamental, if even an a priori, step in considering regulatory choices. See Stephen M. Bainbridge, Mandatory Disclosure: A Behavioral Analysis, 68 U. Cin. L. Rev. 1023, 1032 (2000) ("If the market can efficiently price securities, the market will also efficiently allocate capital investment. ... In order to efficiently price securities, investors must have a constant flow of complete and accurate information.").

${ }^{48}$ Thus, the first level of regulatory response to reducing the frequency of pumpand-dump schemes is by mandating trading brokers have in their possession reasonably current information for non-exchange listed securities before initiating a trade on behalf of a client. See Initiation or Resumption of Quotations Without Specific Information, Exchange Act Rule, 17 C.F.R. $§ 240.15 c 2-11$ (2008). 
would be an information void that allows the unscrupulous promoter to carry out her fraudulent scheme. Finally, mandatory disclosure both empowers stockholders vis-à-vis the firm's managers and restrains opportunistic behavior by company managers. ${ }^{49}$ Disclosure not only nurtures the managers' responsiveness to their stockholders, certainly in connection with any regulated proxy solicitation, but also can attract a bid for control. Additionally, there is a fear that in the absence of mandatory disclosure managers will time their disclosures so as to maximize gains they can reap through insider trading. ${ }^{50}$ A further fear is that absent reliable information, managers may capture a disproportionate value of the firm through artful timing of going private transactions or other forms of restructuring. By providing information regarding the company's performance and its managers' stewardship in a timely manner, mandatory disclosure rules are believed to reduce the frequency of these ill effects. As this Article examines below, most of these objectives are adversely affected if IFRS and GAAP are permitted in a single market.

\section{A. Informing Investors}

If the sole objective of securities regulators is facilitating investors' ability to make meaningful comparisons among issuers on the basis of publicly available information, regulators should be reasonably comfortable with mutual recognition in the GAAP-IFRS context, at least if securities are priced in a market that is fundamentally efficient. Investor judgments respecting investment opportunities are at a socially desirable level of acuity if investors can price securities accurately so that any disclosure lacunae of one is-

\footnotetext{
${ }^{49}$ The classic statement of this objective is Paul G. Mahoney, Mandatory Disclosure as a Solution to Agency Problems, 62 U. Chi. L. Rev. 1047, 1051, 1077-80 (1995) (supporting the view that the goal of securities law is curbing managerial opportunism by dominance of management-focused disclosure items in the Securities Act's Schedule A). But see Alan R. Palmiter, Toward Disclosure Choice in Securities Offerings, 1999 Colum. Bus. L. Rev. 1, 27-29 (1999) (questioning the efficiency of mandating disclosure rules designed to reduce agency costs).

${ }^{50}$ See John C. Coffee, Jr., Market Failure and the Economic Case for a Mandatory Disclosure System, 70 Va. L. Rev. 717, 739-41 (1984) (hypothesizing that in the absence of mandatory disclosure, the popularity of the management leveraged buyout would likely increase as managers attempt to appropriate a greater share of the firm's value).
} 
suer vis-à-vis another issuer are reflected in a heavier discounting of the price of the former over the latter. Importantly, under the assumption of fundamentally efficient capital markets, the amount of that discount will capture the disclosure risk posed by the lower disclosing firm accurately. Here we can see the strong similarity between the arguments in support of multiple disclosure standards and the longer-lasting debate regarding the social benefits of mandatory disclosure rules. Opponents of mandatory disclosure requirements have argued that mandatory disclosure rules are superfluous or at least impose costs in excess of their benefits. ${ }^{51}$ To such critics, the costs of mandatory disclosure rules are unnecessary because they believe investors in a laissez-faire environment can selfprotect through discounting the returns of issuers based on the relative completeness and trustworthiness of their disclosures. ${ }^{52}$ It is also argued that those who advocate mandatory disclosure re-

\footnotetext{
${ }^{51}$ For a review of this debate, see Louis Loss \& Joel Seligman, 1 Securities Regulations 171-93 (4th ed. 2006); Coffee, supra note 50, at 717-18; Joel Seligman, The Historical Need for a Mandatory Corporate Disclosure System, 9 J. Corp. L. 1, 1-9 (1983).

${ }^{52}$ The fount of the empirical battle over the utility of mandatory disclosure rules was Professor Stigler's classic work, Public Regulation of the Securities Markets. George J. Stigler, Public Regulation of the Securities Markets, 37 J. Bus. 117 (1964). Professor Stigler's assault was followed by a series of articles by George Bentson arguing that mandatory disclosure rules provide no significant protection to investors that were not present prior to 1933. See, e.g., George J. Bentson, Required Disclosure and the Stock Market: An Evaluation of the Securities Exchange Act of 1934, 63 Am. Econ. Rev. 132, 151-52 (1973); George J. Bentson, The Value of the SEC's Accounting Disclosure Requirements, 44 Acct. Rev. 515, 531 (1969). The empirical weaknesses and overall validity of the findings of Stigler and Bentson have long been the source of lively debate and analysis. See, e.g., Irwin Friend \& Edward S. Herman, The S.E.C. Through a Glass Darkly, 37 J. Bus. 382, 402-03 (1964); Seligman, supra note 51, at 10 18. Professor Fox has provided a fresh and insightful critique of this work and how the data amassed by Professors Stigler and Bentson poorly support their attack on mandatory disclosure rules. See Merritt B. Fox, Retaining Mandatory Securities Disclosure: Why Issuer Choice is Not Investor Empowerment, 85 Va. L. Rev. 1335, 1369-93 (1999). There are inherent methodological problems with studies of Depression-era markets because of the difficulties of isolating the phenomenon to be examined from all the other forces then affecting securities markets. A useful focus for the value of mandatory disclosure-because it does not confront such multi-confounding economic forces-was the 1964 expansion of mandatory disclosure to over-the-counter securities. See Allen Ferrell, Mandatory Disclosure and Stock Returns: Evidence from the Over-the-Counter Market, 36 J. Legal Stud. 213, 213-16 (2007) (revealing that volatility of over-the-counter stocks to then exchange listed securities declined after SEC reporting status was mandated).
} 
quirements ignore the incentives managers have to disclose information voluntarily. ${ }^{53}$ Most recently, the axis of this debate has shifted. Today, critics, while appearing to accept mandatory disclosure, advocate that issuers should enjoy unrestrained choice of which disclosure regime they will employ to satisfy their disclosure obligations. ${ }^{54}$ Thus, we can see there is at best a slender divide between the arguments of those who question the mandatory disclosure rules and those who champion a multiple disclosure standards approach. ${ }^{55}$ Such similarity is understandable, even predictable,

\footnotetext{
${ }^{53}$ See, e.g., Easterbrook \& Fischel, supra note 40, at 682-84.

${ }^{54}$ There is quite an extensive literature on the topic of regulatory choice for securities laws. See, e.g., Stephen J. Choi \& Andrew T. Guzman, Portable Reciprocity: Rethinking the International Reach of Securities Regulation, 71 S. Cal. L. Rev. 903, 904 08 (1998) (setting forth the argument that issuers should be free to choose which body's law will guide its disclosures); Paul G. Mahoney, The Exchange as Regulator, 83 Va. L. Rev. 1453, 1453-56 (1997) (arguing that exchanges, not the SEC, should regulate disclosure since they are in a better position to understand and be responsive to competing needs of buyers and sellers); Palmiter, supra note 49, at 4-5 (supporting issuer choice conditioned on continuing application of general anti-fraud provision); Roberta Romano, Empowering Investors: A Market Approach to Securities Regulation, 107 Yale L.J. 2359, 2361 (1998) (suggesting that state, not federal, regulation should dictate the demands of mandatory disclosure). To the extent each of these approaches invites choice on the part of the individual firm's managers, it likely invites opportunistic choices on the part of managers that may not always be guided by the interests of the firm. See Amir N. Licht, Genie In A Bottle? Assessing Managerial Opportunism in International Securities Transactions, 2000 Colum. Bus. L. Rev. 51, 88-89 (2000) (reviewing evidence that managers frequently pursue where to seek a listing with a healthy regard to the managers' interests). On the broader question of the desirability of issuer choice, see James D. Cox, Regulatory Duopoly in U.S. Securities Markets, 99 Colum. L. Rev. 1200, 1237-44 (1999) (maintaining that multiple standards in a single market likely would prove unworkable for enforcement); Robert A. Prentice, Regulatory Competition in Securities Law: A Dream (That Should Be) Deferred, 66 Ohio. St. L.J. 1155, 1155-58 (2005).

In the background of whether issuer choice is socially optimal is something of a chicken-and-egg problem in that cross-country comparisons of relative benefits and costs of particular regulatory schemes must deal with the problem that social welfare is fed by a wider range of inputs than simply the strength of a particular country's securities laws. See, e.g., Mark J. Roe, Rents and their Corporate Consequences, 53 Stan. L. Rev. 1463, 1464-65 (2001) (linking labor laws, ownership concentration, and competition to governance norms adhered to by a public company).

${ }^{55}$ Fox summarizes this point:

The proponents of issuer choice .... [O]ffer a different alternative to mandatory disclosure from the one presented by its earlier opponents. Mandatory disclosure's early critics would have allowed issuers to be bound by no regime. Romano and Choi and Guzman, on the other hand, would require each issuer to follow some disclosure scheme but would permit the issuer to choose which one. This new alternative to mandatory disclosure, however, shares with the old
} 
since, if markets are fundamentally efficient, investors do not need the paternalism provided by the costly mandatory disclosure requirements to price securities appropriately. ${ }^{56}$ While the purpose here is not to review the debate on the necessity of mandatory disclosure requirements, it is relevant to place that debate within the context of multiple disclosure standards.

To be sure, in a market that is fundamentally efficient, if the goal is solely to facilitate comparability, the life of the securities regulator would be a quiet one. The classic goal of facilitating informed investment decisions would reduce the regulator to the rather menial task of making sure that issuers disclosed enough information so that investors are aware of the nature of the disclosure differences among issuers. ${ }^{57}$ Thus, in evaluating issuers $G, G^{\prime}, I$, and $I^{\prime}$, the role of the securities regulator would be to assure that the disclosure differences among the four issuers were adequately dis-

alternative at least one core feature: Each grants issuers substantial freedom to choose their own disclosure levels.

Fox, supra note 52, at 1340 .

${ }^{56}$ The divide that separates advocates of multiple disclosure standards from those who favor the host market setting minimum standards for its markets is based on a belief that managers will not eagerly volunteer information when it does not maximize their own utility to do so. Support for the latter is found in the numerous studies that have examined the behavior of managers in the one area where voluntary disclosure is the norm: the proffering of financial forecasts. Studies of financial forecasts consistently reflect the grave reluctance of managers to disclose unexpected bad news. Not only is there evidence that managers systematically delay the release of unexpected bad news forecasts, but managers also systematically time their purchases and sales of their company's securities so as to reap significant insider trading profits based on their private knowledge of the information to be disclosed in the financial forecasts. For a review of the studies, see James D. Cox, Insider Trading Regulation and the Production of Information: Theory and Evidence, 64 Wash. U. L.Q. 475, 49295 (1986). In light of such analogous evidence, we might speculate on just what we would expect to find in a world without mandatory disclosure requirements with respect to any type of information. Here, our expectations are informed by insights from the behavioral sciences, and we could reasonably conclude that the incentives needed to cause managers to disclose information are driven upward by the so-called "status quo bias," which naturally exists and causes greater rewards to be expected to change behavior from the norm believed to be acceptable. Thus, if the norm is that of voluntary disclosure, much greater incentives must be provided to managers to encourage disclosure than in a world in which mandatory disclosure is the norm. See Bainbridge, supra note 47, at 1048.

${ }^{57}$ Regulators would, of course, continue to have an important role in prosecuting fraudulent or manipulative practices. See, e.g., Easterbrook \& Fischel, supra note 40, $678-80$. 
cernible so that these pricing differences would occur. ${ }^{58}$ By so acting, the regulator can rest assured that at least one of the objectives of securities regulations has been satisfied.

\section{B. Allocational Efficiency}

As seen earlier, in the host market where $X$ and $Y$ trade, the securities regulator contributes to allocation efficiency ${ }^{59}$ by mandating line of business reporting. This occurred under the example because disclosure of revenues and profits for the issuer's line of businesses caused $X$ and $Y$ Issuers' prices to separate so that each type of issuer would be priced at its intrinsic value. Now consider the impact of the entry of $I$ and $I$ '. Their presence returns mispricing to the host market because, at least for these two securities, they either will be under- or over-priced. ${ }^{60}$ At the same time, both $I$ and $I$ ' are riskier than $G$ and $G$ ' since their expected value is the combination of their future potential outcomes, which have a greater variance than for $G$ or $G$ '. Investors will not shy away from purchasing either $I$ or $I$ ', provided the expectation of accurately identifying which stock is $I$ and reaping a $\$ 1$ gain is sufficient compensation for the risk involved in making that investment choice.

To illustrate the connection with allocational efficiency, assume that each of the four issuers will undertake a public offering of 50 million shares. The distribution will therefore result in $I$ ' receiving $\$ 50$ million more than its U.S. match, $G$; and $I$ receives $\$ 50$ million less than its U.S. match, $G{ }^{61}$ The regulator will view the loser in this process as not solely $I$ but the host country's investors who

\footnotetext{
${ }^{58}$ Professors Choi and Guzman would call upon the regulators to assure there was minimal disclosure of any disclosure differences. See Choi \& Guzman, supra note 54, at 926 ("Domestic lawmakers ... may place a duty on broker-dealers to notify investors of the law governing transactions in a particular company's securities.").

${ }^{59}$ For a tightly developed argument concerning why a market that is fundamentally efficient will not necessarily lead to allocational efficiency because managers may themselves misinterpret the risks and returns of business opportunities, see Jeffrey N. Gordon \& Lewis A. Kornhauser, Efficient Markets, Costly Information, and Securities Research, 60 N.Y.U. L. Rev. 761, 767-69 (1985).

${ }^{60}$ See supra text accompanying note 44.

${ }^{61}$ Readers are reminded of the earlier stated assumption that share prices are efficiently priced in light of information that is publicly available. Thus, $I$ indeed has an intrinsic value greater than the value embedded in its market price because the market price does not reflect the private information that would call for a higher market valuation.
} 
chose I' over the other three investment choices. The regulator has good cause to believe that if all issuers selling securities within its jurisdiction abided by its mandatory disclosure rules that there would have been more accurate pricing of the issued securities and investors could have better maximized their investment return. And, assuming that capital is not unlimited, some issuers may have been able to distribute more of their own securities if there had been a level disclosure field since factors disclosed per GAAP may reflect greater future risks for $I$ and $I$ ' than for other capital-hungry issuers. ${ }^{62}$

Accurate securities prices also affect the disciplining effects of the market for control, which has its own impact on the role that securities markets play in the allocation of capital. Mandatory disclosure rules enhance the likelihood that managers who perform poorly by making suboptimal uses of the resources under their control will be displaced. Those who replace them can be expected to better deploy the firm's resources. Thus, if the cause of differences between $I$ and $I$ ' issuers is that $I$ firms have talented managers and $I$ ' do not, the pricing of $I$ firms so that they are indistinguishable from $I$ ' firms will mean $I$ ' managers will continue to be immune from the disciplining effects of a takeover or proxy contest so that $I$ ' firms' resources will continue to be misallocated. ${ }^{6}$

\footnotetext{
${ }^{62}$ For the view that price inaccuracy in the host market has ill effects only for the home country of the foreign issuer, see Merritt B. Fox, The Securities Globalization Disclosure Debate, 78 Wash. U. L.Q. 567, 579 (2000). Since the issuers compete for capital against one another, to the extent regulation creates advantages for one group of issuers over another competing group of issuers, it is hard to understand why the ill effects would not be felt in the host country if it is their issuers who are disadvantaged by the competitive advantage given to the foreign issuers. Moreover, if the foreign issuer uses the proceeds so raised for expansion of its operations in the host country, then to the extent that one were persuaded to focus narrowly by Professor Fox's call essentially to "follow the money," the effects of the advantage would be even more clearly felt in the host country.

${ }^{63}$ Thus, we would find that if bidders could not distinguish $X^{\prime}$ from $Y^{\prime}$ issuers, the effect would be to insulate underperforming firms from takeovers since their securities are overpriced. This problem may well be de minimis in the host market, because an insignificant percentage of the company's securities are traded within the host market in contrast with its home market. The disciplining effects of takeovers can therefore be seen as a governance issue that is traditionally commended to the home market. Although there may be some unequal treatment of investors in the host market, the same de minimis considerations can cause regulators to permit departure from the host market's traditional rules regulating the conduct of tender offers as the regulator balances the benefits of those rules versus the social cost of bidders structur-
} 
Thus, under a mutual recognition-multiple standards approach, the well-meaning regulator loses its ability to influence the allocation of capital. Even $G$ ' Issuers may suffer because investors are attracted to the prospects of the rewards of identifying an $I$ Issuer by the fifty percent odds of acquiring an IFRS reporting firm at \$21 that becomes a $\$ 22$ security. Domestic issuers lose; indeed, all issuers lose if investment funds are diverted to lower disclosing firms. As developed above, the lower disclosing firms pose greater risk, but their greater risk will not prevent them from attracting capital if investors perceive the reward of accurately picking an $X$ class issuer. And, the lower disclosing firms' managers also face a reduced likelihood of being disciplined by the market for control. ${ }^{64}$ Each effect interferes with the regulators' quest to enhance allocational efficiency in their market.

\section{Reduction of Fraudulent Offerings}

The securities regulator's role in deterring fraudulent offerings occurs on two fronts: ex ante through mandating disclosures that reduce the likelihood $^{65}$ of such an offering occurring ${ }^{66}$ and ex post

ing their tender offer so as to foreclose participation by investors outside the target's home market. This thinking is reflected in the SEC's rules regarding cross-border tender offers involving non-domestic issuers. See Scope of and Definitions Applicable to Regulations 14D and 14E, 17 C.F.R. $\$ 240.14 d-1$ (b) (2001). See generally Jill E. Fisch, Imprudent Power: Reconsidering U.S. Regulation of Foreign Tender Offers, 87 Nw. U. L. Rev. 523, 523-25 (1993).

${ }^{64}$ A key component of the argument that managers should be completely passive in the face of a hostile takeover of their company is the view that the target company's shares are priced efficiently. See Frank H. Easterbrook \& Daniel R. Fischel, The Proper Role of a Target's Management in Responding to a Tender Offer, 94 Harv. L. Rev. 1161, 1161-64 (1981).

${ }^{65}$ By requiring certification of financial statements and even expert opinions from other outside experts, such as attorneys, on matters relevant to an offering of securities, and by imposing on each not only liability for reasonable care with respect to such undertaking, but also liability under the anti-fraud provision in all securities transactions, mandatory disclosure essentially conscripts independent professionals to the role of gate keepers, thus providing a separate counterforce to fraudulent offerings.

${ }^{66}$ Professor Stigler's analysis of performance relative to a market index of securities offered between 1949 and 1955, compared with those offered between 1923 and 1928, led him to conclude that an ill effect of mandatory disclosure is the systematic exclusion of risky companies from public markets. Stigler, supra note 52, at 122. Such exclusion is seen more positively by others who conclude that the greater disclosure and verification that was introduced by the securities laws had the natural effect of permit- 
enforcement of applicable antifraud provisions so that the sanctions imposed upon fraudsters will deter others from engaging in fraudulent securities offerings. Superficially, the embrace of dual reporting standards would not appear to have an adverse impact on the securities regulator's important role of deterring fraudulent offerings through its enforcement of applicable antifraud provisions. It would seem that the sanctions to be applied would be those of the host country so one could expect that the sting of the enforcement efforts would not be diminished. ${ }^{67}$ However, on closer analysis, deterrence will be affected to the extent the principlesbased approach of IFRS has the effect of making violations more difficult for regulators to both detect and prosecute successfully. Indeed, those who call for principles-based regulation do so with an equally forceful call that regulation should be prudential, that is, not enforcement oriented. ${ }^{68}$ Consequently, any substantive ambiguity or weaknesses in IFRS will carry forward to the enforcement actions by the host regulators and will weaken the deterrent effects of its enforcement actions. As a consequence, fraud will occur with greater frequency if issuers can opt for weaker disclosure standards so that the host country is hobbled in deterring the occurrence of fraud because the selected regime's laws provide weaker enforcement procedures and powers than do the host country's laws.

Moreover, the assumption that offerings will be priced efficiently does not protect investors from fraudulent offerings. This pricing assumption assumes disclosure of enough information so that investors can appropriately discount the purchased security by the disclosure risks it presents. Fraudulently offered securities by definition will be indistinguishable from other securities, except that securities opting for more rigorous disclosure regimes pose a lower risk of fraud than those securities choosing a less rigorous disclosure regime. To be sure, investors can be expected to impound in their pricing decisions the average risk of fraud for all securities.

ting fewer risky offerings since the enhanced disclosure that risky issuers had to make could be expected to cause investors not to purchase their offerings, and thus discourage the would-be issuers from making the offering at all. See Friend \& Herman, supra note 52, at 390-91.

${ }^{67}$ See Cox, supra note 54, at 1239-43.

${ }^{68}$ See Comm. on Capital Mkts. Regulation, The Competitive Position of the U.S. Public Equity Market (2007), available at http://www.capmktsreg.org'pdfs/ The_Competitive_Position_of_the_US_Public_Equity_Market.pdf. 
Such an averaging, however, is a tricky, and most likely indeterminate, calculation. Theoretically, investors should divide securities according to the disclosure regime each has opted to use and discount each security within the group by the average risk of fraud posed by all securities in that group. So viewed, this risk is systematic so that it cannot be diversified away; the larger and more diverse one's portfolio, the closer the portfolio's overall risk of holding fraudulent offering will be to the risk of fraud in the market as a whole.

The significance of the risk of a fraudulent offering not being a diversifiable risk is that when the well-diversified investor has the misfortune (statistically predictable though it is) to hold a fraudulently offered security that becomes worthless, or nearly so, the investor's loss is not recouped from the other securities in the investor's portfolio. Each of the remaining securities remain subject to the disclosure risks that were embedded in them when the investor acquired them and those disclosure risks will cause them to carry the same discount for their respective disclosure risks when resold by the investor. That is, the result of holding a diversified portfolio is not like squeezing a balloon, where pressure at one spot causes an equal expansion at another location. This merely reflects the well-recognized principle that the presence of fraudulent offerings that cannot be detected ex ante through prevailing disclosure procedures lowers the value of all offerings. At the same time, the risk being systematic does lead to all investors expecting compensation for their bearing this risk; thus, the expected return for investors is greater than if this risk were not present. Stated differently, much like the rising tide that lifts all boats, fraudulent offerings that cannot be identified ex ante raise the cost of capital for all issuers. This increases the cost of capital for all companies issuing securities; but when one considers that companies that raise capital by issuing securities compete with other investor opportunities that do not raise funds in securities markets and that involve no risk of managerial oppression, one can also see its effects on the efficient allocation of investment dollars. ${ }^{69}$

\footnotetext{
${ }^{69}$ See James D. Cox, Insider Trading and Contracting: A Response to the "Chicago School," 1986 Duke L.J. 628, 635-42.
} 
The securities regulator seeking to prevent fraudulent securities offerings ex ante in a multiple disclosure standards approach faces a very circumscribed agenda. Powerless to regulate substantive disclosures of issuers opting to be governed by another disclosure regime, the most the regulator can hope to accomplish is to inform investors of the greater likelihood of fraud associated with the disclosure regime selected by an issuer. This course is similar to that discussed earlier in terms of the host regulator's task in facilitating the efficient pricing of securities so that differences in disclosure practices are impounded in the security's price. The most that can be accomplished through such generic warnings is to cause each purchased security to be priced at an amount that reflects the average risk of fraud among securities opting for that particular disclosure regime. But as seen above, even so discounted, if the investor experiences a loss from a fraudulent offering, the magnitude of that loss is not offset by discounts for the other securities in the investor's portfolio.

\section{Managerial Responsiveness to Owners and Opportunistic Behavior}

Mandatory disclosure rules are also a central component of corporate governance. For example, proxy voting for public U.S. corporations is conditioned upon the proxy solicitor making extensive disclosure of information germane to shareholders exercising informed decisions when executing their proxies. ${ }^{70}$ Absent such disclosures, shareholders would be left to the weak disclosure requirements of state law and the vagaries of fiduciary-based disclosure duties of directors and controlling stockholders. ${ }^{71}$ Federal disclosure requirements overcome these weaknesses so that managers approach the proxy season with a healthy understanding that their stewardship in the prior fiscal period must be adequately

\footnotetext{
${ }^{70}$ The disclosures that must be satisfied by a U.S. reporting company in connection with the election of directors is set forth in Schedule 14A. Also, there is the further requirement that management's solicitations relating to a meeting at which directors will be elected must be accompanied by an annual report to shareholders. See Information to be furnished to Security Holders, 17 C.F.R. § 240.14a-3(b) (2008).

${ }^{71}$ See generally James D. Cox \& Thomas Lee Hazen, 1 Cox \& Hazen on Corporations 542-45 (2d ed. 2003) (reviewing basis for officers' and directors' disclosure obligations and the limited enforcement options available for their breach).
} 
disclosed in their proxy materials. Among the disclosures compelled by any SEC filing requirement are detailed revelations regarding various self-dealing transactions between the corporation and its promoters, managers, or controlling stockholders, ${ }^{72}$ including extensive information regarding executive compensation. ${ }^{73}$ The securities laws' requirement that the annual financial statements be independently audited is a further effort to provide owners with a neutral perspective of management's stewardship. ${ }^{74}$ In this way, many of the disclosures required to accompany management's proxy solicitation materials mirror disclosures mandated by the home country's periodic disclosure requirements. A major objective of periodic disclosure requirements is to overcome the fear that, absent such mandated disclosures, financially important information would not be released until the managers had reaped for themselves the financial benefits of that information by trading in their company's securities before releasing the information. ${ }^{75}$ Without adequate disclosure of information bearing on the value of the firm, managers can, through self-dealing transactions and going private transactions, abuse their insider positions by capturing a disproportionate share of any undisclosed future gains of the firm. ${ }^{76}$ To the extent that IFRS results in greater price inaccuracy than is the case for issuers complying with GAAP, does this necessarily compromise the securities regulator's role in addressing managerial opportunism?

\footnotetext{
${ }^{72}$ See Transactions with Related Persons, Promoters and Certain Control Persons, 17 C.F.R. § 229.404 (2008) (detailing disclosures required for related party transactions exceeding $\$ 120,000$ ).

${ }^{73}$ See Executive Compensation, 17 C.F.R. $\$ 229.402$ (2008) (calling for specific information to be disclosed on a wide range of benefits to senior executives, but also containing principles-based guidance on annual compensation disclosure and analysis of executive compensation).

${ }^{74}$ See 17 C.F.R. $\$ \S 210.2-01-210.2-02$ (setting forth detailed requirements respecting the auditor's independence and the content of the auditor's opinion respecting the reporting company's financial statements).

${ }^{5}$ See generally Cox, supra note 56, at 477 (reviewing weaknesses in incentives for managers to voluntarily release financially significant information).

${ }^{76}$ See Bernard S. Black, The Legal and Institutional Preconditions for Strong Securities Markets, 48 UCLA L. Rev. 781, 782-85 (2001) (concluding that the better the overall financial disclosure regime, the harder it is for self-dealing to be concealed); see also supra notes $49-50$ and accompanying text.
} 
Allowing issuers to report their financial performance and position in accordance with IFRS rather than GAAP would not obviate the extensive disclosures public companies must satisfy that are directed specifically toward transactions rife with opportunities for managerial opportunism. Not only would SEC registrants still have to provide extensive information for various self-dealing transactions, but they would also have to comply with requirements for the company to have an independent auditor review the financial statements and under the watchful eye of an audit committee staffed with directors free of financial links to the firm's management. In combination, these requirements provide an important firewall between the firm's assets and temptations managers may have to appropriate to themselves any portion of the firm's value that is not otherwise known.

Nonetheless, permitting managers to opt for disclosure standards understood to provide them with greater discretion in the timing of revenues and expenses and the measurement of assets and liabilities provides serious temptations for those inclined to act opportunistically. Simply stated, the greater the price inaccuracy permitted by a disclosure regime, the greater will be the temptations for managers to use the inaccuracies to their advantage.

\section{E. Synopsis}

We find, therefore, that in a market assumed sufficiently efficient to price the lacunae that prevail between GAAP and IFRS, nearly all the objectives traditionally associated with securities regulation stand substantially qualified. ${ }^{77}$ Only the objective of

${ }^{77}$ The assumption made in this Article that capital markets are fundamentally efficient is not a strong one. There is abundant evidence that conditions that would characterize such markets do not exist. See Eugene F. Fama, Market Efficiency, LongTerm Returns, and Behavioral Finance, 49 J. Fin. Econ. 283, 285-88 (1998). Even studies that reject the hypothesis that securities markets are fundamentally efficient, however, are not inconsistent with the belief that securities prices respond rapidly to financially significant information. This state of efficiency, referred to here as securities markets being informationally efficient, poses a more difficult environment for justifying a multiple disclosure standards approach under the traditional objectives of securities regulation.

To illustrate the functioning of an informationally efficient market, return to the earlier illustration of two firms, $X$ and $Y$, where without line of business information investors are unable to distinguish the higher valued $X$ firms $(\$ 22)$ from the lower valued $Y$ firms (\$20). Investors estimate the value based upon broad sets of informa- 
tion bearing on each firm's past, present, and future performance. In a market that is only informationally efficient, investors will have heterogeneous expectations regarding what to make of each bit of information within these sets so that the security's resulting price will reflect their ranging estimates. See Lynn A. Stout, How Efficient Markets Undervalue Stocks: CAPM and ECMH Under Conditions of Uncertainty and Disagreement, 19 Cardozo L. Rev. 475 (1997). Thus, it is not possible to conclude, as we did earlier, that in an informationally efficient market investors would, absent line of business information, price $X$ and $Y$ securities at their combined weight of $\$ 21$. Instead, investors can be expected to disagree about the value of $X$ and/or $Y$ firms generally so that the security's price will reflect-most likely on an on-going basis-their disagreement whether the intrinsic value of $X$ shares is greater or less than $\$ 22$. Similar disagreements will occur for Firm $Y$ shares. Thus, investors in an informationally efficient market will not price $X$ and $Y$ shares at $\$ 21$ when they cannot distinguish $X$ from $Y$ firms; instead, each share will be priced in a range around $\$ 21$ per share. The breadth of that range will be directly related to the degree to which their expectations diverge.

Here we should further consider the impact of a new compelled disclosure, such as the line of business disclosure in the illustration. A new disclosure requirement of financially significant information in an informationally efficient market will likely elicit varying judgments among investors regarding that information's impact on a security's price. Widely varying assessments of the new information's impact will be layered onto the already varying assessments of the firm's risk and return that were formed on the basis of information already available to the public before the new disclosure. Thus, what we observe with the release of financially significant information are security prices that reflect the price changes of such heterogeneous expectations.

Just how satisfying is the life of the securities regulator in a world in which securities prices do not, on average, reflect their intrinsic value? The answer is a crisp "not very" if securities prices bear no observable relationship to the public disclosure of financially significant information. In such a world, the costs of disclosure would be hard to justify since the conclusion that disclosure bears no relationship to securities price changes would suggest that mandatory disclosure has only negative social welfare implications. In fact, regulatory efforts produce a social benefit if they change investor expectations such that securities prices change in response to their reaction to the release of information even though the resulting prices do not reflect intrinsic value, provided the price change is in the direction of the security's intrinsic value. That is, prices over- and under-react but over time migrate toward a security's intrinsic value. Thus, we can see that the security regulator's life is a satisfying one, even if the markets are only informationally efficient.

As seen above, even in an informationally efficient market, the disclosure of line of business information can be expected to move the price of $G$ and $G$ ' securities from their composition price-a price that ranges around $\$ 21$ - toward their respective intrinsic value. The information therefore sharpens the risk and return assessments posed by each security. An important policy question confronts the host regulator if $I$ and $I$ ' securities trade in the same market as do $G$ and $G$, and the former disclosures are guided by IFRS. In an informationally efficient market, investors cannot be expected to price the effect of stronger or weaker disclosure requirements accurately. With respect to a security whose issuer chooses to abide by materially weaker disclosure requirements, we would expect the rational investor to view such a security as presenting a greater inherent risk and to take this into account in pricing the security 
so as to garner a return expected to compensate for the totality of the security's risks. The policy question this raises for the host country's securities regulator is whether there is a net social benefit of permitting this new variable. To be sure, investors will be able to make sharper comparisons if all issuers are bound by the same disclosure rules as apply to $G$ and $G$ '. Permitting $I$ and $I$ ' to adopt different disclosure requirements will result in their prices reflecting greater uncertainty respecting their intrinsic value than will occur for the securities of $G$ and $G^{\prime}$. More important, investors in a market that is only informationally efficient cannot be expected to price accurately the differences in relative risk between, on the one hand $I$ and $I$ ', and on the other hand, $G$ and $G$ '. Just as the objective of comparability was advanced when the securities regulator imposed line of business disclosure requirements with the intended effect of sharpening the distinction between $X$ and $Y$, the objective is undercut if $I$ and $I$ ' can enter U.S. markets without complying with line of business requirements. Simply put, there is no comparability when issuers can provide different levels of disclosure that cannot be reduced to differences that can be accurately reflected in differences in value.

In an informationally efficient market, disclosure requirements that cause a security to trade closer to its intrinsic value or reduce the variance around its intrinsic value necessarily allow investors to make sharper comparisons among investment opportunities. However, a disclosure standard that causes uncertainty regarding a security's risk and return does not enhance investors' comparative judgments, but rather reduces the allocational efficiency of the host markets so that this objective of securities regulation is frustrated. This can be expected to occur because the greater the variance in the price at which $I$ and $I$ ' trade vis-à-vis $G$ and $G^{\prime}$ the more likely that the expected returns associated with $I$ and $I$ ' securities will be inappropriately matched with their risk. In a market that is not fundamentally efficient, this greater variance will not be reflected accurately in the price of any of the securities. The ability of $I$ and $I$ ' firms to employ weaker disclosure requirements in the host market necessarily will have an adverse impact on that market's allocational functioning.

As we saw earlier, the securities regulator's quest to protect its market's investors from fraudulent offerings is an objective that is thwarted by an issuer's ability to use the weaker disclosure requirements of another nation. This result is all the more present when securities markets cannot price the likelihood or magnitude of the potential fraud accurately because the market is only informationally efficient. In such a market, the regulator seeks to protect host country investors by exposing the offering to disclosure and certification processes that will reduce the offering being made in the host market. Here the deterrence effects of mandatory disclosure rules and their accompanying certification procedures are unaffected by whether the market accurately reflects the individual security's intrinsic value. Fraudulent offerings are less likely to occur and their issuers' reputationally conscious accountants, lawyers, and underwriters are less likely to participate in offerings whose disclosures indicate or strongly suggest the likelihood that they are fraudulent. With the option of such issuers to use in the host country another country's weaker disclosure requirements, investors in an informationally efficient market will not be able to price the likelihood of the fraudulent offering. Hence, there is no assurance that over time their losses in connection with such offerings will be compensated by the discounts they have demanded in all such offerings. With their inability to price this risk accurately, the investors may over time be net gainers or losers. 
comparability is satisfied if investors are able ex ante to price the differences between the two financial disclosure regimes accurately; this no doubt reflects a tautology since comparability itself calls for just such accurate pricing of the differences, which is embedded in the assumption of fundamental efficiency. That the other objectives are not satisfied when weaker and stronger standards prevail in a single market invites the next question addressed: how should the SEC respond, particularly in light of the unrelenting and overtaking forces of globalization?

\section{Why Don'T THEy EAT CAKE}

With the assumption that investors can price the lacunae between GAAP and IFRS accurately, the SEC may envision that its role is to sharpen investor awareness of the differences that persist between these two reporting metrics so that investors can better engage in price protection. As seen earlier in Section II.A., this indeed is the strategy recommended if the sole objective of the securities regulator is to facilitate comparison among investors. Thus, if comparability were the sole issue, the SEC could fulfill its regulatory mandate by not terminating issuer's use of GAAP, but rather by allowing issuers to choose between GAAP and IFRS, provided ample disclosure of the generic differences that exist between the two reporting regimes was presented. As developed above, however, even a price protection strategy on the part of investors will not fulfill the objectives of facilitating allocational efficiency, reducing fraudulent offerings, and moderating the temptations for managerial overreaching. What then can be the regulatory strategy for the SEC short of choosing between these two competing regimes?

Another dimension of investor education that is frequently counseled is encouraging investors to maintain well-diversified

Finally, when investors cannot self-protect by pricing securities accurately to reflect the expected level of managerial misbehavior, non-systematic over- and under-priced securities will abound; self-dealing, insider trading, and other opportunistic behavior by managers confront investors with a risk that is imperfectly impounded in securities prices. Because the risk is not accurately priced, any price adjustment will be imperfect and cannot be expected to have the same deterrent effect as would be the case in a market that was fundamentally efficient. Thus, the weaker the disclosure standard, the weaker the deterrence of managerial overreaching will be. 
portfolios. The investor advantages for a diversified portfolio are well understood. Risk is reduced if investors select investments whose returns are not correlated. Thus, the decision of which investment to acquire, and of which to dispose, is one based not on the expected return of that investment, but rather on how that investment's addition to the portfolio contributes to the return and risk of the portfolio as a whole. Commentators have thoughtfully proposed that many a regulatory issue disappears if investors hold diversified portfolios. ${ }^{78}$ For example, Professor Fox concludes that in an efficient market, the price of the security should not be affected by disclosure of such firm-specific information because no rational investor will pay a premium for a risk that could be addressed by diversification. ${ }^{79}$

To examine whether this is a correct understanding of diversification of investments that are each priced in an efficient market, consider again the social costs and benefits of line of business disclosures for the earlier illustration of $X$ and $Y$. Without this disclosure, both would trade at $\$ 21$, since investors would be unable to distinguish which was a $\$ 22$ stock $(X)$ and which was a $\$ 20$ stock $(Y)$. Do we really believe that upon disclosure of this line of business information-that is, firm-specific information-that no one will purchase $X$ shares for more than $\$ 21$ or that investors will continue to purchase $Y$ shares at $\$ 21$ ? Studies persist in documenting

\footnotetext{
${ }^{78}$ See, e.g., Stephen Choi, Regulating Investors Not Issuers: A Market-Based Proposal, 88 Cal. L. Rev. 279, 300-01 (2000) (proposing that unsophisticated investors investment options should be confined to index funds); Frank H. Easterbrook \& Daniel R. Fischel, Corporate Control Transactions, 91 Yale L.J. 698, 713-14 (1982) (finding that ill effects of majority oppression can be addressed through minority investors holding diverse portfolios); Merritt B. Fox, Regulation FD and Foreign Issuers: Globalization's Strains and Opportunities, 41 Va. J. Int'l L. 653, 683-84 (2001) (arguing that investors can self-protect against ill effects of selective disclosure through efficient diversification).

${ }^{79}$ Fox summarizes his conclusion:

When more information is available about an issuer, its share price is likely to be closer, on one side or the other, to actual value. This enhanced accuracy represents a gain to the less than fully diversified investor, because it reduces the risk of holding the issuer's shares in her portfolio. Since the risk that is reduced is unsystematic, however, the issuer's share price will not on average be any higher than it would be absent this disclosure - the fundamental lesson of the capital asset pricing model. Thus, the issuer's managers receive no corresponding reward for the benefit enjoyed by the investors.

Fox, supra note 52, at $1357-58$.
} 
that investors do value firm specific information; the investors' decisions are reflected in the response of the security's price to the release of financially significant information. ${ }^{80}$ Firm-specific information does alter the price of the underlying security, and its disclosure can thereby provide social benefits to the host market. ${ }^{81}$ Clearly, the evidence that firm-specific information is relevant to investors and to the pricing function of markets means that the SEC cannot rest on its oars merely by being satisfied that investors hold efficient portfolios.

Moreover, information that is firm-specific may well portend developments for the firm that become systemic to the firm. For example, an increase in profitability of a distinct line of business can over time increase internal allocations of resources to that area of activity. As a result, the firm's mix of revenue changes with the concomitant effect of altering its overall riskiness vis-à-vis the market. The possibility that this information may not be immediately visible to investors is indeed one of the justifications for line of business reporting, but it also can exist if financial reporting standards permitted managers to dampen reporting of the successes or failures actually occurring within the firm. Even if we assume the information to be disclosed does not change the systematic or industry risk of either $X$ or $Y$, this information can still be socially beneficial (and in turn raises the question of whether the marginal social cost of its production exceeds the expected marginally social benefit) even though it is firm specific. Finally, large numbers of investors are not well diversified, and many that pursue strategies that seek to maximize portfolio returns by considering the individual characteristics of the security, not merely its covariance to the market.

The most fundamental weakness of the portfolio approach is that it fails to distinguish between returns and risk when consider-

\footnotetext{
${ }^{80}$ There are many illustrations, but the most pertinent is how investors react to improved disclosure that occurs when, for example, companies use the more demanding GAAP or IAS, instead of the less revealing German accounting standards. See Bushee \& Leuz, supra note 44, at 257-61.

${ }^{81}$ The classic event studies of accounting items repeatedly reflect that firm-specific decisions yield firm-specific significant stock price changes for information that is financially significant in terms of materially affecting the amount and timing of the firm's cash flow. See, e.g., Robert Kaplan \& Richard Roll, Accounting Changes and Stock Prices, 29 Fin. Analyst J. 48 (Jan. 1973).
} 
ing the benefits of diversification. Adding more stocks to an investor's portfolio is a strategy for reducing the random variable within the return of individual stocks. The unexpected gains of some stocks are offset by the unexpected losses of others. However, to the extent that stocks have a common risky characteristic-for example, they are all shares in pharmaceutical companies-the more pharmaceutical shares that are added to the investor's portfolio the more the risk of the portfolio becomes that of pharmaceutical companies generally. In this way, diversification does not render the risk equal to zero, but causes the portfolio's risk to reflect that of the dominant group of stocks. Thus, using the examples earlier, a portfolio made up of $I$ and $I$ ' securities would have greater risk than a portfolio made up of $G$ and $G^{\prime}$ securities, where $G$ and $G^{\prime}$ are understood as being higher disclosing firms than $I$ and $I$ '. Adding more of the latter to the portfolio moves the overall portfolio risk toward that of the non-GAAP reporting issuers.

\section{RETURNING TO ITS ROOTS}

The preceding analysis shows that the SEC, or for that matter its foreign counterparts, cannot remain committed to the historical objectives of securities regulations merely by public incantations of the benefits of investor diversification or by highlighting differences between GAAP and IFRS. Indeed, the challenges here are even more pervasive than the accounting metrics public companies will use; the very same global competitive forces that drive regulators toward mutual recognition for accounting standards also call for extending commonality with respect to a wide range of disclosure items. Ultimately, regulators must confront, as the SEC is doing today, how to accommodate for all companies non-host country disclosure standards. The full implications of globalized offerings and trading is the death of the regulator's sovereignty. How, then, does the SEC cope in this world? The answer to this question lurks in an understanding of how domestic organizations function in an international setting.

\section{A. Two Views of Making Law in a Globalized Economy}

Though Gaul was divided into three parts, political scientists generally fall into two camps regarding their view of the possibili- 
ties of cooperation through international law: the realist perspective and the liberal/institutionalist perspective. One must regard the present territorially oriented approach to securities regulation as being reflective of the realist school. Despite the pressures of globalization, the realist school believes that a single national standard for each nation will be the most likely outcome. The realist perspective is generally attributed to a reaction to post-World War I Wilsonian liberal internationalism. Realists rejected Wilson's embrace of international organizations, such as the League of Nations, as well as the concept of collective security as vehicles to replace war and power politics. Realists explained international politics in terms of antinomy: law versus power; the domestic real versus the international unreal; cooperation versus conflict; moralism/idealism/utopianism versus reality. ${ }^{82}$ Though this may strike one as being a bit divorced from the arcane topic of securities regulation, we are drawn closer to these juxtapositions by their unifying thesis: nations champion only their own national interests. Incantations regarding the preeminence of U.S. capital markets and the rigors of its regulation are repeatedly joined as justifications for the status quo of U.S. regulatory treatment of foreign issuers. Until recently, only isolated accommodations were made for foreign issuers $^{83}$ and, with the exception of Canadian issuers, ${ }^{84}$ all had to abide

\footnotetext{
${ }^{82}$ The founding works of modern realists are Edward H. Carr, The Twenty Years' Crisis, 1919-1939 (2d ed. 1964); George F. Kennan, American Diplomacy, 1900-1950 (1951); Hans J. Morgenthau, Politics Among Nations: The Struggle for Power and Peace (5th ed. 1973). For an excellent review of these works and that of others, see Anne-Marie Slaughter Burley, International Law and International Relations Theory: A Dual Agenda, 87 Am. J. Int'l L. 205, 207-14 (1993).

${ }^{83}$ The annual form required of foreign issuers to satisfy the U.S. periodic disclosure requirements, Form $20-\mathrm{F}$, was amended so that it conformed to that embraced by the International Organization of Securities Commissions, but the accommodation did not change the overall scope and degree of disclosure so required. See International Disclosure Standards, Securities Act Release No. 33-7745, 64 Fed. Reg. 53,900, 53,901, 53,906 (Oct. 5, 1999), reprinted in [1999-2000 Transfer Binder] Fed. Sec. L. Rep. $(\mathrm{CCH})$ II 86,208 (Sept. 28, 1999). And, some requirements regarding accounting reconciliations to GAAP are relaxed for foreign issuers. See generally James D. Cox et al., Securities Regulation 221-23, 551-53 (5th ed. 2006).

${ }^{84}$ See Multijurisdictional Disclosure and Modifications to the Current Registration and Reporting System for Canadian Issuers, Securities Act Release No. 33-6902, 56 Fed. Reg. 30,036, 30,036-37 (July 1, 1991), reprinted in [1991 Transfer Binder] Fed. Sec. L. Rep. (CCH) II 84,812 (June 21, 1991).
} 
by the same disclosure standards that pertained to U.S. issuers. ${ }^{85}$ The close observer of U.S. positions on transnational securities regulatory issues finds resonance in the insights of the leading contemporary realist, Professor Kenneth Waltz. He views the organizing thesis of understanding international relations as that of an anarchic order because there is no higher government above the world's nations. Within this world, nations are preoccupied with power and security issues and international organizations only marginally affect prospects of cooperation. ${ }^{86}$ In the important issue of war and peace, the absence of an overarching authority creates the void in which fear and distrust among nations abound. ${ }^{87}$ For the more mundane topic of securities regulation, we find the independent pursuit of the content of securities regulation. In such a world, the realists posit that public policy is guided not by the goal of achieving the highest individual payoff from a domestic initiative, but rather "to prevent others from achieving advances in their relative capabilities." $\$ 8$ Simply put, nations are more concerned with maintaining their position with an emphasis on preventing others from improving their capabilities. ${ }^{89}$

It is on the last two points that the realist thesis diverges from objective evidence of practices pursued by the SEC. Though the SEC has a long history of being a relatively inflexible rampart against pressures to reduce the rigors of U.S. disclosure standards for foreign issuers, it has been anything but obstructionist in the efforts of sister nations to raise their own regulatory standards and capabilities. Indeed, an important focus of the SEC has been its interaction with individual nations and international organizations to promote their development of regulatory standards that approach

\footnotetext{
${ }^{85}$ Foreign issuers with shares listed on a U.S. exchange are exempt from U.S. proxy disclosure requirements and the short-swing profits filing and disclosure requirements. See Exemptions from Sections 14(a), 14(b), 14(c), 14(f) and 16 for Securities from Certain Foreign Issuers, 17 C.F.R. $§ 240.3 a 12-3$ (2008).

${ }^{86}$ See Kenneth N. Waltz, Theory of International Politics (1979).

${ }^{87}$ Id. at 113; Joseph M. Grieco, Anarchy and the Limits of Cooperation: A Realist Critique of the Newest Liberal Institutionalism, 42 Int'l Org. 485, 497-98 (1988).

${ }^{88}$ Grieco, supra note 87, at 498; see Carr, supra note 82, at 111; Robert Gilpin, War and Change in World Politics 87-88 (1981).

${ }^{89}$ See Grieco, supra note 87, at 499; Emerson M. S. Niou \& Peter C. Ordeshook, Realism versus Neoliberalism: A Formulation, 35 Am. J. Pol. Sci. 481, 484 (1991).
} 
those of the United States. ${ }^{90}$ At this level, the SEC appears to reflect the view of the liberal/institutionalist school that it is possible for nations - democracies in particular - to adopt and adhere to international or multiple regulatory standards in a sustainable fashion. The rise of transnational corporations and the expansion of international trade are among the events that challenge the realist view of the continued supremacy of the rules of an individual nation as an instrument of international politics. And, with the collapse of the Soviet Union, security concerns, certainly for developed countries, were replaced by economic concerns. ${ }^{11}$

The focus of the liberal/institutionalist is:

[how] interactions among states and the development of international norms interact with domestic politics of the states in an international system so as to transform the way in which states define their interests. Transnational and interstate interactions and norms lead to new definitions of interests, as well as to new coalition possibilities for different interests within states. ${ }^{92}$

There are important illustrations supporting the hopefulness that underlies so much of the cooperative scheme that the liberal/institutionalist believes is possible. ${ }^{93}$ Among the most powerful evidence in favor of the liberal/institutionalist approach is the phenomenon known as the "democratic peace"-in short, the longstanding, and by now well-tested, observation that established de-

\footnotetext{
${ }^{90}$ See generally James R. Doty, The Role of the Securities and Exchange Commission in an Internationalized Marketplace, 60 Fordham L. Rev. S77 (1992); Caroline A.A. Greene, Note, International Securities Law Enforcement: Recent Advances in Assistance and Cooperation, 27 Vand. J. Transnat'l L. 635 (1994). More recently, the SEC spearheaded a global memorandum of understanding on enforcement. See SEC Announces IOSCO Unveiling of Multilateral Agreement on Enforcement Cooperation, SEC News Dig., Issue 2003-208 (Oct. 31, 2003), available at http://www.sec.gov/news/digest/dig103103.txt (announcing multilateral agreement for sharing information among international regulators related to ongoing enforcement matters).

${ }^{91}$ See Joseph S. Nye, Jr., Neorealism and Neoliberalism, 40 World Pol. 235, 236 (1988). This arguably remains the same notwithstanding Russia's ongoing departure from democracy and the aggressive tenure of the Putin regime.

${ }^{92}$ Id. at 238.

${ }^{93}$ See Charles W. Kegley, Jr. The Neoidealist Moment in International Studies? Realist Myths and the New International Realities, 37 Int'l Stud. Q. 131, 135-38 (1993).
} 
mocracies rarely, if ever, go to war with one another. ${ }^{94}$ There is a long tradition of attempts to explain the causes of democratic peace, extending back to the philosopher Immanuel Kant. ${ }^{95}$ Not the least important among the explanations offered is the observation that peace and cooperation among democratic states on both economic and security affairs are made possible by their institutional structures - that is, transparency that permits open observation of policy choices, clear rules for continuity of governance, electoral accountability of political leaders, and constitutional governance. ${ }^{96}$ These structures, taken as a whole, make democracies more reliable and predictable partners in the conduct of their international affairs, particularly with respect to the enforcement of their international agreements.

Supportive of the vision of democratic peace has been the willingness of certain nations, such as those in Europe, to cast aside important aspects of their sovereignty and integrate their economies, ${ }^{97}$ as well as the well-documented practices of many states to adhere voluntarily to international law even in circumstances where compliance runs counter to their immediate self-interest. ${ }^{98} \mathrm{~A}$ leading scholar in this area is Professor Robert Keohane, who has shown how international regimes or institutions can and have facilitated cooperation among governments, not by mandating what they should do, but rather by helping governments pursue their own interest through cooperation. ${ }^{99}$ Thus, the liber-

\footnotetext{
${ }^{94}$ For an excellent presentation of the democratic peace thesis, see Charles Lipson, Reliable Partners: How Democracies Have Made a Separate Peace 1 (2003) (indicating that the correlation holds not just for established democracies but also for newer, unstable democracies, which, as a general matter, are also reluctant to go to war with one another).

${ }^{95}$ See James D. Morrow, International Conflict: Assessing the Democratic Peace and Offense-Defense Theory, in Political Science: The State of the Discipline 172, 177 (Ira Katznelson \& Helen V. Milner eds., 2002) (providing a succinct overview of democratic peace theory).

${ }^{96}$ See Lipson, supra note 94 , at 14.

${ }^{97}$ See Charles W. Kegley, Jr., The New Containment Myth: Realism and the Anomaly of European Integration, 5 Ethics \& Int'l Affs. 99, 109-12 (1991).

${ }^{98}$ See Dorothy V. Jones, Code of Peace: Ethics and Security in the World of Warlord States (1991); Christopher.C. Joyner, The Reality and Relevance of International Law, in The Global Agenda 202 (Charles W. Kegley, Jr. \& Eugene R. Wittkopf eds., 3d ed. 1992).

${ }^{99}$ Robert O. Keohane, After Hegemony: Cooperation and Discord in the World Political Economy 9, 13 (1984).
} 
als/institutionalists do not reject the importance of national selfinterest, but see that international cooperation, perhaps through an international organization, can indeed empower nations. ${ }^{100}$

There is no central supreme authority to which all nations' securities regulators are accountable. Individual nations share a common view of the importance of securities regulations in the development and maintenance of their own economy. As seen earlier, there are four very broadly recognized objectives sought by securities laws. Though these objectives have broad support across nations, currently nations vary widely in the details regarding how these objectives are to be achieved. And of even more importance to this Article, nations differ regarding both the regulatory costs they are willing to impose on issuers and the protection they afford to investors.

A central issue, however, is given certain assumptions about the efficiency of capital markets, whether and to what extent the objectives are compromised if a nation's regulatory system cannot control the minimum level of disclosure that is to apply in its markets. On the one hand, if regulators and nations are persuaded that ceding local control does not seriously compromise the domestic interest embodied in the objectives of their securities laws, even the realist can envision cooperative action among nations. On the other hand, if regulatory objectives are seriously compromised, the liberal/institutionalist school provides a hopeful note that strong national interest may over time interact to lead to cooperative efforts that reduce differences. But to do so, there needs to be an understanding of just what local objectives are compromised, and to what a nation gains and what it loses when it forsakes its approach for that of another. The earlier portions of this Article counsel that strong, and not divergent, standards better fulfill the overall objectives of an individual nation's securities laws. At the same time, the forces of globalization are so unrelenting and powerful that there can hardly be room for the realist school's preoccupation with each country's securities regulations being an island unto itself. Thus, the model for action by the SEC is that of engagement and cooperation that is consistent with the liberal/institutional view.

\footnotetext{
${ }^{100}$ Id. at $244-45$.
} 


\section{B. A Strategy for the SEC in a Global Marketplace}

Three decades ago, the SEC confronted an early challenge of globalization and did so in a manner that mirrors the position of the liberal/institutionalist perspective. Trading on inside information was occurring in U.S. markets through Swiss bank accounts shielded from the inspection of regulators, domestic or foreign, by local blocking statutes. ${ }^{101}$ This development gave rise to a concerted SEC effort to enter into a series of Memoranda of Understanding ("MOU's") with governments around the world that ultimately had the effect of lifting regulatory standards and protections around the world. ${ }^{12}$ Today, we might well consider mutual recognition as the medium for achieving what earlier occurred via the individually negotiated MOU's.

When insider trading entered U.S. capital markets from abroad, it signaled that the world had significantly shrunk so that effective investor protection called for the SEC to become a statesman à la the liberal/institutionalist view; it did not respond as a well-armed domestic enforcer by muscling foreign regulators in a manner predicted by the realist school. The SEC met the challenge confronting U.S. markets by raising standards around the globe for regulating insider trading and enforcement. Indeed, for decades the SEC has been an active agent for change in international securities markets with the result that markets around the world have become more efficient, transparent, and trustworthy. Indeed, it is likely the success in its efforts in improving regulation in other markets that explains why U.S. markets do not enjoy the dominant position they did even ten years ago. ${ }^{103}$ The fact that the regulatory gap has nar-

${ }^{101}$ The SEC's foray into this area was on a precedential blank slate. See Sec. Exch. Comm'n v. Certain Unknown Purchasers of the Common Stock of, and Call Options for the Common Stock of, Santa Fe Int'l Corp., Fed. Sec. L. Rep. II 99,424, at 99,424 (S.D.N.Y. 1983) (seeking to freeze assets believed linked to insider trading profits); Sec. Exch. Comm'n v. Banca Della Svizzera Italiana, 92 F.R.D. 111, 112-13 (S.D.N.Y. 1981) (seeking a temporary asset freeze of funds linked to the suspected insider trading).

${ }^{102}$ See generally Michael D. Mann et al., The Establishment of International Mechanisms for Enforcing Provisional Orders and Final Judgments Arising from Securities Law Violations, 55 L. \& Contemp. Probs. 303 (Autumn 1992) (describing the history of the SEC's efforts to weave a network of MOU's to address insider trading that ultimately lifted regulatory standards around the world).

${ }^{103}$ See, e.g., Jim O'Neill \& Sandra Lawson, Is Wall Street Doomed?, Global Econ. Wkly., at 1-4 (Feb. 14, 2007) (finding that diminishing foreign IPOs and fewer secon- 
rowed, whether a lot or just somewhat, between U.S. markets and major foreign markets provides an easier ground for mutual recognition to occur in ways that are more likely to fulfill each of the four regulatory objectives of host market securities laws. There simply is less ground to close today between U.S. markets and say London, Frankfurt, or Tokyo.

Thus, the strategy for the United States is the earlier one pursued with insider trading: engagement, persuasion, and perseverance. But in this quest, timing is important. For example, it quite likely was a wise choice for the SEC to cast aside the need for foreign issuers to reconcile their financial statements to GAAP, provided they employ high-quality IFRS for their financial reporting. The reconciliations were months late so that the report that mattered was their earlier-released IFRS-based financial reports. ${ }^{104}$ And, as to those reports, evidence suggests that U.S. analysts deferred to foreign analysts for critical analysis of this information since the former were not skilled or experienced in IFRS. ${ }^{105}$ Thus, the GAAP-based reconciliation came too late and was an easy requirement to cast aside.

Nonetheless, the proposal that U.S. issuers will be permitted, or required, to use IFRS may be premature. This conclusion is most solidly based on the evidence, reviewed earlier, that convergence between GAAP and IFRS is not yet complete. And, more important, there is a fundamental divergence with respect to the political culture by which financial reporting standards are to be established by the IASB and the political culture surrounding the FASB. As seen earlier, a significant contribution of the SOX in 2002 was conditioning the SEC's acceptance of an authoritative accounting standard setter on that body meeting certain requirements for independence in the appointment of its members and, most signifi-

dary listings by foreign issuers in the United States is not attributable to overregulation in the United States but to rising strength of foreign markets as well as historical predilection for offerings and trading to occur near the issuer's home market).

${ }^{104}$ The deadline for Form $20-\mathrm{F}$ and its reconciliation is six months following the close of the foreign issuer's fiscal year.

${ }^{105}$ Ramona Dzinkowski, Saying Goodbye to U.S. GAAP, Strategic Fin. 46, 47-48 (June 2007) (reporting that of 165 companies rated by Moody's, only thirteen had analysts in the United States while others were covered by foreign analysts versed in IFRS reporting). 
cantly, its funding. ${ }^{106}$ This provision was designed to overcome the heavy self-interest reporting companies had exerted through their auditors' willingness to support, through voluntary contributions, the work of the FASB prior to the enactment of SOX. It is equally premature to discuss abandoning GAAP without a full understanding of what strategies the SEC can employ to influence standard setting in a body located in London rather than Stamford, Connecticut, the present location of the FASB. To paraphrase a famous remark by Justice William O. Douglas, just what weapon will the SEC keep behind the door to assure that the IASB meets the minimal expectations of the SEC? ${ }^{107}$

One likely strategy will be for the SEC to reserve, and discretely exercise, the option to compel supplemental disclosures, particularly when it believes IFRS provides too weak a standard. ${ }^{108}$ To exercise this option, and to be a constructive participant in the delib-

${ }^{106}$ See Sarbanes-Oxley Act of $2002 \S 108$ (b)(1)(iii), Pub. L. No. 107-204, 116 Stat. 745, 768 (2002) (codified as amended at 15 U.S.C. $\$ 77 \mathrm{~s}(\mathrm{~b})(1)($ iii) (2006)) (amending Securities Act of $1933 \S 19$ (b)(1)(iii), 48 Stat. 74).

${ }^{107}$ See William O. Douglas, Democracy and Finance 82 (James Allen ed., 1940) (recalling a previous observation that in regards to the SEC's interface with the selfregulatory role envisioned for the exchanges "[g]overnment would keep the shotgun, so to speak, behind the door, loaded, well oiled, cleaned, ready for use but with the hope it would never have to be used").

${ }^{108}$ The interaction among regulators envisioned as a necessary component of mutual recognition is superior to all-out regulatory competition. The latter is not likely to succeed since the conditions for productive competition among regulators does not exist. See William W. Bratton \& Joseph A. McCahery, The New Economics of Jurisdictional Competition: Devolutionary Federalism in a Second-Best World, 86 Geo. L.J. 201, 206-07 (1997) (reviewing conditions believed to be necessary for productive regulatory competition and finding they exist only in the idealized world of assumptions); Cox, supra note 54, at 1232-33. If there were such competition it need not lead to a race to the bottom. See Eric J. Pan, Harmonization of U.S.-EU Securities Regulation: The Case for a Single European Securities Regulator, 34 Law \& Pol'y Int'l Bus. 499, 531 (2003) (explaining that before Prospectus Directive ushered in the portable passport for offerings and pubic listings there was little evidence that regulatory competition among E.U. members entailed a race to the bottom). Absent evidence that states will seek to dilute standards provides a hopeful note that engagement followed by a mutual recognition strategy will yield stronger, not weaker, overall regulation. There are those, however, who see divergence among regulators as a strength. They believe that regulators who provide multiple competing options will, much like the market for apples, yield a better allocation of results. See Stephen J. Choi \& Andrew T. Guzman, National Laws, International Money: Regulation in a Global Capital Market, 65 Fordham L. Rev. 1855, 1879-81 (1997) (favoring a separation rather than a pooling equilibrium among regulators). 
erations overseen by the IASB, the SEC must have an effective accounting staff. It may well be that its current staff needs to have the same level of technical support and broad input to its operations as presently enjoyed by the FASB. Because standard setting is ongoing and no accounting convention or principle can be expected to endure without recurrent valuation, the SEC needs a body to support its statutory obligation for setting financial reporting standards for U.S. capital markets. Just as U.S. product safety standards should not be outsourced to an international organization without at least meaningful oversight by a domestic agency, so it is that we should not cede authority over the metrics for financial reporting to an international body without being assured that our regulator has the expertise and resources to evaluate whether the metrics support the objectives sought by U.S securities laws. It thus seems wise to carry forward in some manner the important role that the FASB has played and will continue to play toward convergence of reporting standards. This observation reflects the reality that convergence is not a point in time, but rather a continuum whereby nations, through their separate organizations, continue to engage one another. While such a robust operation may strike some as confrontational to the IASB, it should be seen as continuing the United States' commitment to high-quality reporting standards around the world. 